\title{
Conceptual Models of 1200 years of Icelandic Soil Erosion Reconstructed Using Tephrochronology
}

\author{
Andrew J. Dugmore ${ }^{1}$, Gudrún Gísladóttir², Ian A. Simpson³ ${ }^{3}$ and Anthony Newton ${ }^{1}$
}

\begin{abstract}
With reference to 18 tephra isochrones, we present six reconstructions of landscapes in South Iceland at precise times through the last 1200 years and develop three related models of soil erosion. Before the late ninth century A.D., the landscapes of Iceland were without people and resilient to natural processes. The initial impact of human settlement in the ninth century AD was most profound in ecologically marginal areas, where major anthropogenic modifications of the ecology drove geomorphological change. In the uplands, overgrazing contributed to the formation of a dense patchwork of breaks in the vegetation cover where soil erosion developed and resulted in the rapid denudation of large areas. As the upland soils were shallow (generally $<0.5 \mathrm{~m}$ ), the overall impact of erosion on total aeolian sediment fluxes before AD 1510 was modest. Later erosion of the deeper lowland soils (generally $>2 \mathrm{~m}$ ) involved a lower spatial density of eroding fronts and a slower loss of soil cover, but a much greater movement of sediment. Land-management strategies, changes in species patterns of plant communities, extreme weather events, and climate changes have combined in differing degrees to initiate and drive rates of soil erosion. Sensitivity to change and the crossing of erosion thresholds has varied through time. The record of soil erosion has major implications for both archaeology and contemporary land management.
\end{abstract}

\section{Introduction}

Iceland provides rare opportunities to assess human impacts on soil erosion and landscape change. Before the Norse settlement, or Landnám of the ninth century A.D., there is no evidence of people in Iceland (Buckland et al. 1995, Fridriksson 1994). As a result, it is possible to identify environmental records from long periods of the Holocene, during climates similar to, warmer, and cooler than today that have no anthropogenic components (Caseldine 1987; Dugmore 1987, 1989; Stötter 1991). Contrast can be drawn with records from the last 12 centuries when the changing climates of the "Medieval Warm Period" (Grove and Switsur 1994) and "Little Ice Age" (Grove 1988) have been interwoven with extensive human impacts on the landscape (Arnalds 1987, Runolfsson 1978, Thomson and Simpson 2007). At present, however, chronologically precise and spatially explicit models of long-term landscape change in Iceland are lacking. Spatial and temporal patterns of tephra deposition provide one means of creating detailed models of change that can be tested and used to develop understanding of the interplay of different processes over diverse landscapes through century-millennia timescales. In this paper, we focus on a district of southern Iceland and use 18 tephra isochrones to develop six reconstructions of Icelandic landscapes at precise times through the last 1200 years.

\section{Landscape change in Iceland}

The Norse colonists introduced herbivorous mammals to Iceland for the first time, rapidly building up populations of sheep, goats, pigs, cattle, and horses (Amorosi et al. 1997). Woodland and scrub were cleared, and field systems established (Vésteinsson 1998). Up to the $20^{\text {th }}$ century, livestock grazed all year round, and farms had access to common summer pastures extending up to 500-600 m above sea level (Fridriksson 1973, Thoroddsen 1919).

Vegetation cover in Iceland $\left(103,000 \mathrm{~km}^{2}\right)$ has diminished significantly since early Norse settlement. Today it is about $28 \%$ of the island's area (LMI 1993) as opposed to much more extensive presettlement vegetation cover estimated to be between 54\% (Ólafsdóttir et al. 2001) and 65\% (Thorsteinsson 1986) of total land area. The composition of the vegetation cover has also greatly changed; estimates of woodland coverage at the time of settlement vary from 15,000 $\mathrm{km}^{2}$ (14.5\%)-40,000 $\mathrm{km}^{2}$ (39\%) (Bergthorsson 1996, Bjarnason 1974, Einarsson 1962, Olafsdottir et al. 2001, Sigurdsson 1977, Thorarinsson 1961, Thorsteinsson 1986), whereas present woodland coverage is 1\% (LMI 1993). Changes in the species composition of plant communities, their distribution, and overall vegetative cover, have been related to enhanced soil erosion, increased aeolian sediment fluxes, slope instability, and hydrological changes (e.g., Arnalds 1987; Arnalds et al. 2001a; Dugmore et al. 2000; Einarsson 1961, 1963; Gísladóttir 1998; Hallsdóttir 1987; Haraldsson 1981; Ólafsdóttir et al. 2001; Thorarinsson 1961; Thorsteinsson 1986, 2001). The changes in both the extent and nature of vegetation cover have been attributed to direct or indirect anthropogenic effects acting in combination with unfavorable climate and erodable soils.

\footnotetext{
${ }^{1}$ School of GeoSciences, University of Edinburgh, Edinburgh EH8 9XP, Scotland. ${ }^{2}$ Department of Geology and Geography, University of Iceland, 101 Reykjavík, Iceland. ${ }^{3}$ School of Biological and Environmental Sciences, University of Stirling, Stirling FK9 4LA, Scotland. *Corresponding author - andrew.dugmore@ed.ac.uk.
} 
Andisols, which are of volcanic origin, cover $78,000 \mathrm{~km}^{2}$ or $86 \%$ of Iceland (Arnalds 2004) and have a high susceptibility to cryoturbation, landslide, wind, and water transport (Arnalds 1999, Wada et al. 1992). Recent investigation of soil erosion in Iceland (Arnalds et al. 2001a) has shown that almost $41,000 \mathrm{~km}^{2}$ (or about $40 \%$ of the country) is characterized by severe soil erosion, and this has created a variety of landforms. The largest areas of severe soil erosion are deserts (as defined by Arnalds et al. 2001a), of which sandy surfaces form nearly 22,000 $\mathrm{km}^{2}$ (Arnalds et al. 2001b). Other erosion forms are the rofabard type (a bank of eroding soil that separates areas denuded of soil from surviving

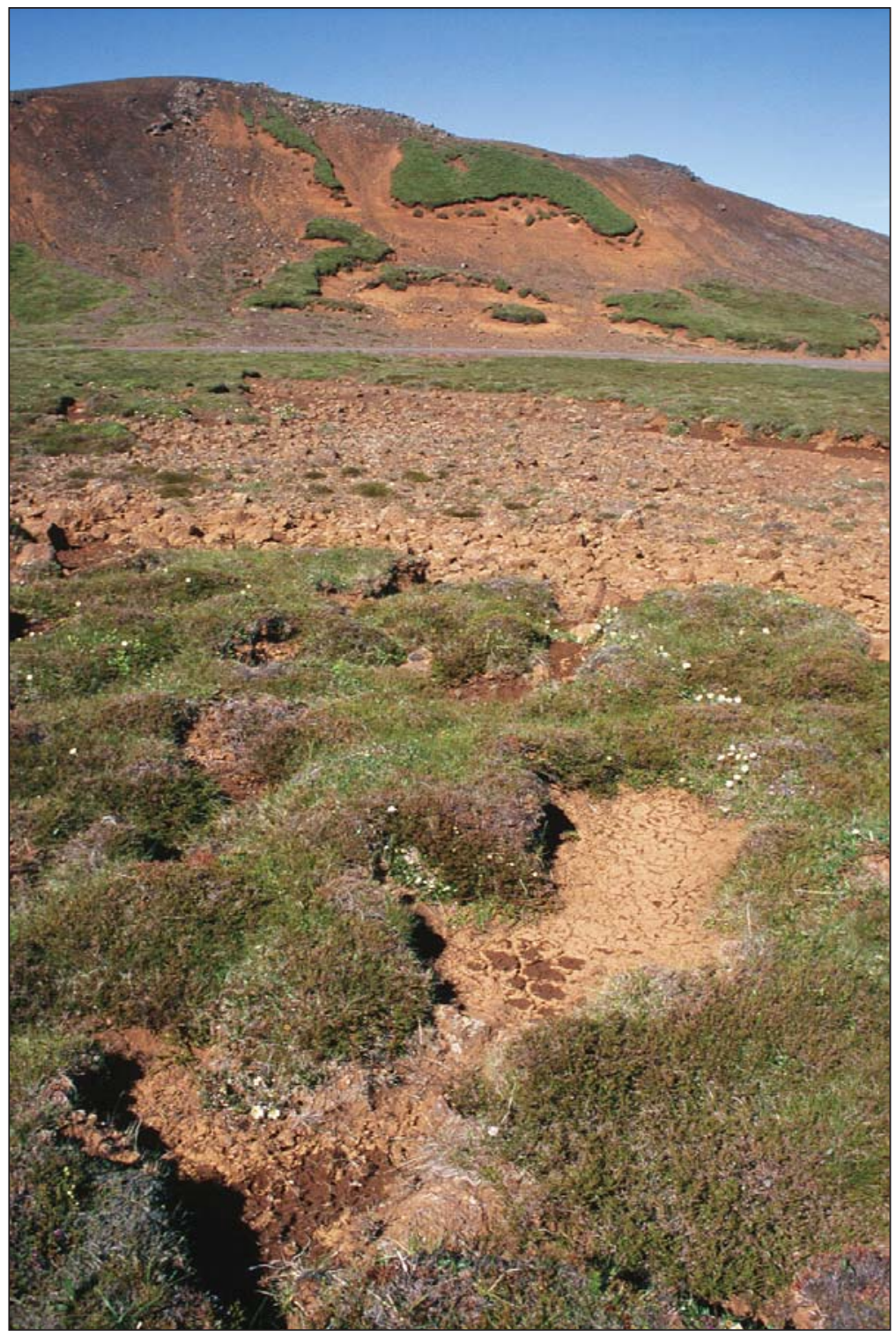

Figure 1. A characteristic suite of Icelandic soil erosion forms. In the foreground, erosion spots have developed. At these sites, wind will remove exposed sediment (some of which maybe subsequently trapped by the surrounding vegetation). On the hill slope in the background, rofabards have formed where eroding soil slopes are cutting into a once ubiquitous vegetation and sediment cover. Photograph (c) Guðrún Gísladóttir. areas of soil and vegetation), which cover about $3600 \mathrm{~km}^{2}$, and erosion spots within vegetated areas, which are found across about $2700 \mathrm{~km}^{2}$ (Fig. 1). Based on the erosion rate around rofabards, Arnalds (1999) has suggested that erosion associated with present rofabards has denuded 15,000-30,000 km² of land.

Conceptual models of ecological changes in Iceland due to grazing have been used to explain both the susceptibility of the land to soil erosion and various erosion forms (Aradóttir et al. 1992, Gísladóttir 2001). Both models identify key changes in vegetation from continuous covers of palatable deciduous shrubs, grasses, and broad-leaved herbs to less-productive heathland dominated by unpalatable evergreen dwarf shrubs and narrow-leaved herbs. Development of heathland communities is suggested to have occurred at the expense of woodland and herb communities, and leads to increased susceptibility of the plant community to land degradation. Indeed, it is possible that the heathlands of Iceland may mostly represent remnants of the original homogenous woodlands and their once fertile soils. Gísladóttir (2001) has described the effect of micro-scale patterns of species abundance on soil erosion, identifying heterogeneous dwarf-shrub heath as potentially very susceptible to spot erosion and more homogeneous grass heath as less susceptible. In thick soils, erosion spots can expand and form into rofabards. Homogenous grassland with thick root mat is, however, resilient and does not easily form erosion spots, but may be systematically reduced in extent by rofabard encroachment from the edges of the plant community (Fig. 2).

Overall, these conceptual models of changes in plant communities and related increases in susceptibility to soil erosion aid explanation of rapid vegetation decline and accelerated soil erosion. In Iceland, landscape change is a product of a complex interaction between natural environmental processes and human activities, both of which are heavily influenced by past events. Through time, the sequence of changes at a particular place will give an area a unique character. The spatial variability caused by accumulated changes may tend to obscure the function of fundamental processes. The 
challenge is to disentangle the sequence of events and interacting processes. In Iceland, this clarification of the record may be done with unparalleled precision because of a very well-developed tephrochronological system of dating control (Fig. 3).

\section{Approach, Methods, and Data Sources}

\section{Tephrochronology}

Tephrochronology, based on the identification, correlation, and dating of layers of volcanic ash or tephra (Thorarinsson 1944), has many potential applications in geomorphology (Self and Sparks 1981, Thorarinsson 1981). The great chronological importance of tephra layers is their rapid formation and wide dispersal, which means that they can be used to define extensive, and very precise, timeparallel marker horizons or isochrones (Sparks et al. 1997). Extreme events have formed tephra horizons of continental scales (e.g., Cas and Wright 1987,
Fisher and Schminke 1984). At a regional scale, Icelandic volcanoes have formed $>200$ Holocene tephras covering areas from $10^{2}-10^{6} \mathrm{~km}^{2}$ (Dugmore et al. 1995; Einarsson et al. 1980; Larsen 1982, 1984, 1996; Larsen and Eiríksson 2008a, 2008b; Larsen and Thorarinsson 1977; Larsen et al. 1999; Thorarinsson 1967, 1975, 1980, 1981). Tephrochronologies are based on the identification, correlation, and dating of a number of separate tephra deposits to define a series of isochrons (Thorarinsson 1944, 1981). Resulting geomorphological applications of tephrochronology and tephra stratigraphy can be developed to differing degrees.

At one level of application, tephra deposits may be used to provide limiting dates on geomorphological features, such as till units and moraines (e.g., Dugmore 1989, Stötter 1991, Thorarinsson 1956). This use of tephrochronology is very effective in providing spot dates in particular profiles, but it does not necessarily use the spatial attributes of

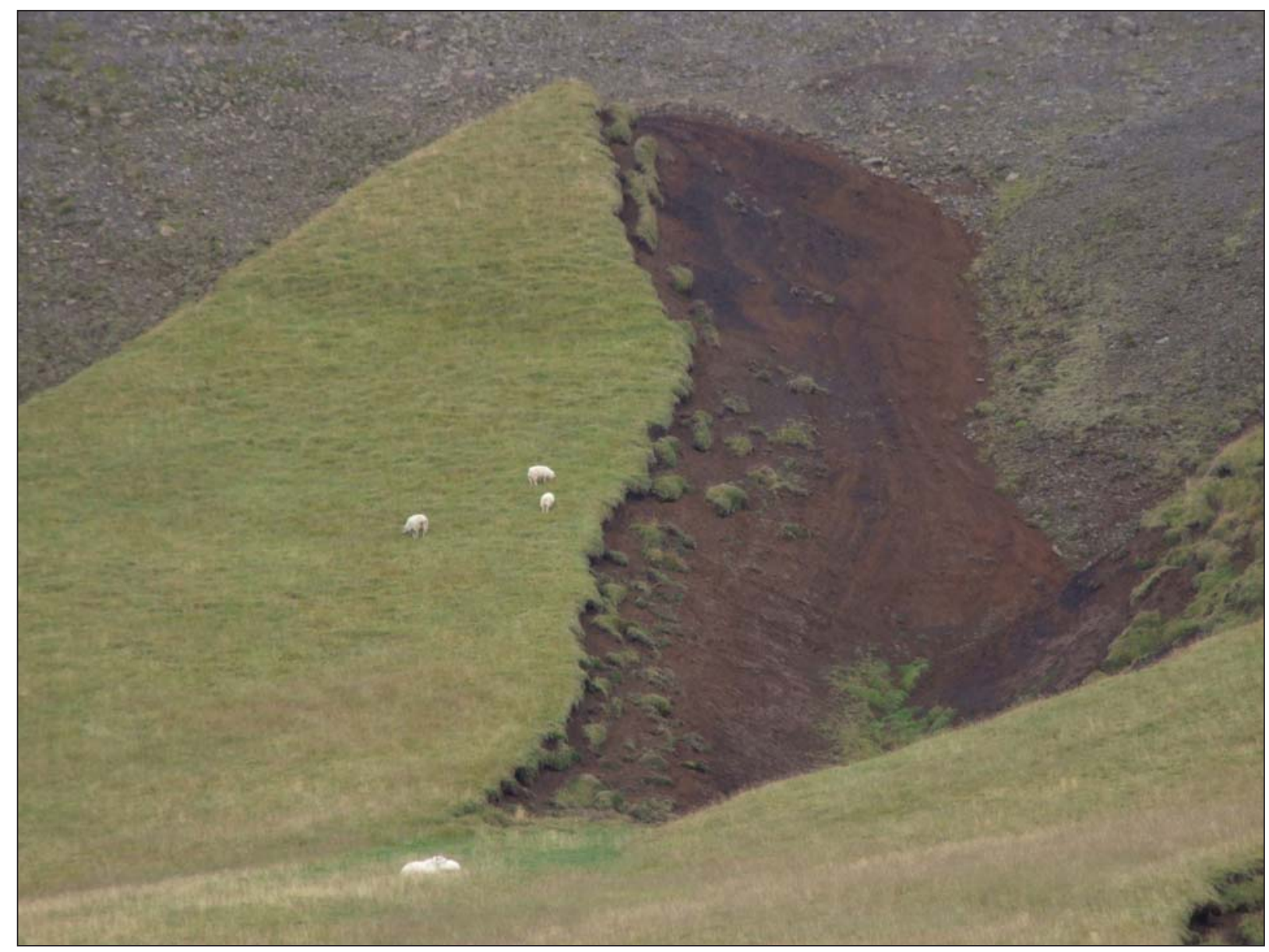

Figure 2. A rofabard in South Iceland (ca. 44 m north of point 251; Fig. 5). The exposed soil slope is eroding to reduce the area of vegetated deep soil (where the sheep are grazing). Most of the soil depth, which includes visible outcrops of black tephra layers, prehistoric in age, has accumulated since the deglaciation of this area ca. 8000 years ago. Glacially divided sediments that mantle this underlying hill slope can be seen across the top of the picture and on the upper left-hand side and upper right-hand side. As erosion proceeds, sediments are deposited on the vegetation, thereby thickening the surviving soil profile. The dense vegetation and thick root mat of the grassland has resisted the development of erosion spots. Photograph (C) Andrew J. Dugmore. 
the isochronous horizons defined by the tephras. If tephra layers are identified at a number of sites, they can be used to both define isochrones and intervals of time and determine the spatial dimensions of rates of change (e.g., Dugmore and Buckland 1991; Dugmore et al. 2003, 2007; Thorarinsson 1961). This application can allow precise 3 -D reconstructions to be made. The use of tephrochronology can be refined further when the form of the tephra layer and its 3-D geometry within the stratigraphic sequence are also used to infer the operation of past geomorphic processes, such as solifluction and cryoturbation (e.g.,

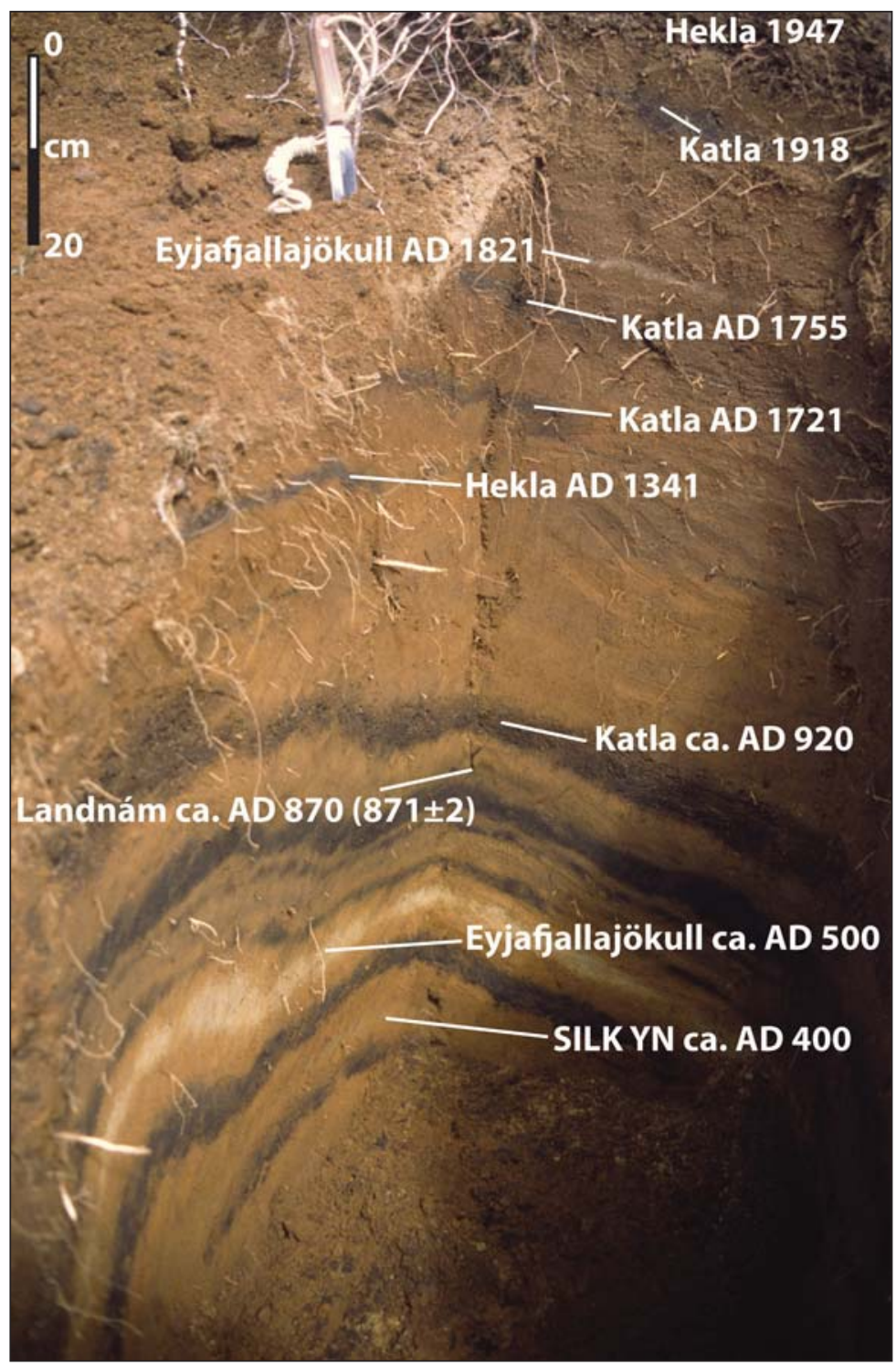

Figure 3. A typical soil profile close to Gígjökull (Fig. 5) showing tephra layers used in this study (e.g., Fig. 8). In the sediment sequences formed before Landnám, tephra layers (dark and white layers) make up a greater proportion of the stratigraphy than aeolian soils (brown sediment). This profile is a reflection of both lower aeolian sediment accumulation rates and thinner tephra layers. The layers in the lower, central part of the profile form even layers; vegetation cover disrupted the layers to the lower left-hand side, and frost action has disturbed the upper right-hand side of the profile (compare to Fig. 4). Photograph (C) Anthony J. Newton.
Dugmore and Erskine 1994, Kirkbride and Dugmore 2005, Thorarinsson 1961) (Fig. 4). Tephrochronology can therefore provide a particularly powerful chronostratigraphic framework that may be used to develop models of landscape change in general and geomorphological change in particular.

\section{The study area}

The district around Eyjafjallajökull was chosen as a study area because of the wide range of landscapes present and the natural barriers that define two hreppur, or communities organised around common grazing resources (Fig. 5). The barriers formed by the Mýrdalsjökull icecap and the Markarfljót and Jökulsá rivers effectively constrain rangeland grazing, creating a coherent district for an assessment of anthropogenic impacts. The hreppur extend from coastal sandur to the upland glacier margins and include inland valleys. This topographic range is important because it contains three key pre-Landnám habitats: marshy lowland sandur with occasional stands of trees, forested areas with deep soils ( $>2 \mathrm{~m}$ ), and upland heaths and grassland with shallow soils ( $<0.5 \mathrm{~m})$ (Fig. 6). Palynological research (Erlendsson 2007) shows that the wooded lowland at Stóra-Mörk soon changed after landnám as the landscape became increasingly open. In these lowlands, Betula spp. (birches) had more or less disappeared by the $12^{\text {th }}$ century, although some woodland lingered into the late medieval time. The identification of charcoal production pits has enabled the utilization of Betula spp. to be tracked up valley to Langanes (Dugmore et al. 2006). Precise dating based on a combination of tephrochronology, sediment accumulation rates, and radiocarbon dates combined in a Bayesian analysis, has revealed two phases of exploitation between cal AD 870-1050 and cal 1185-1295 (Church et al. 2007). Charcoal production based on Betula spp. comes to an end in Langanes by the $14^{\text {th }}$ century. By AD ca. $1417-1510$ in the lowlands at Stóra-Mörk, heathland expansion (represented by increasing Empetrum nigrum [black crowberry]) probably made the vegetation more susceptible to land degradation (Erlendsson

Figure 5 (opposite page, bottom). The study area. The inset shows the location within southern Iceland. Soil profiles 201-213 are located at Kroshóll (see also Fig. 12). 


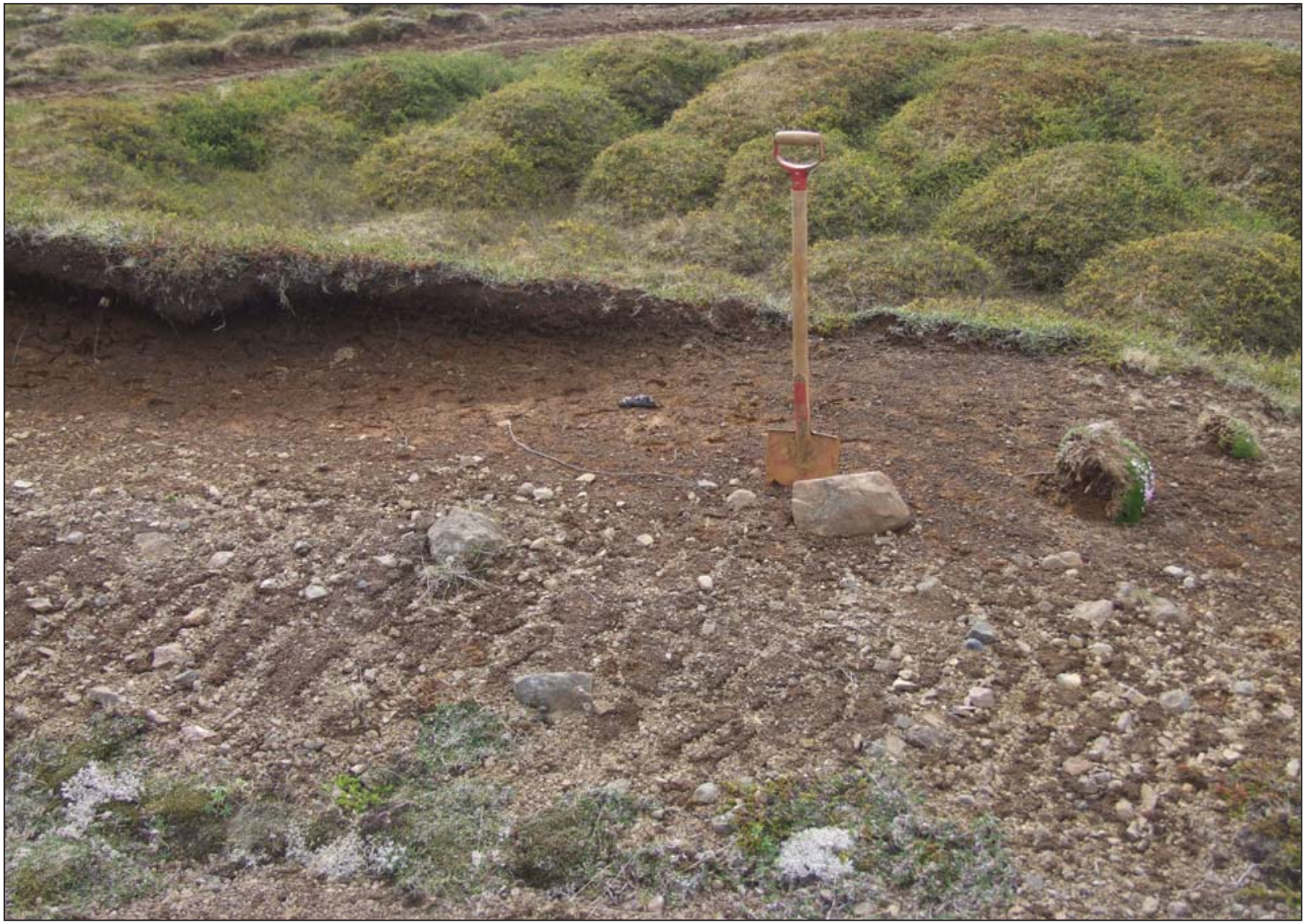

Figure 4. Frost structures in soils in northeast Iceland $\left(66^{\circ} 3^{\prime} 24^{\prime \prime} \mathrm{N}, 15^{\circ} 47^{\prime} 20^{\prime \prime} \mathrm{W}\right)$. In the background, cryoturbation has formed well-developed thufur, or frost hummocks. The internal features of these structures can be revealed by tephrochronology (Fig. 11). In the foreground, an eroding slope is propagating away from the camera, stripping away the shallow aeolian soil cover to reveal the underlying glacial sediment. Where the soil cover is shallow $(<10 \mathrm{~cm})$, stone stripes have formed that cross the eroding slope at right angles. Photograph (c) Andrew J. Dugmore.

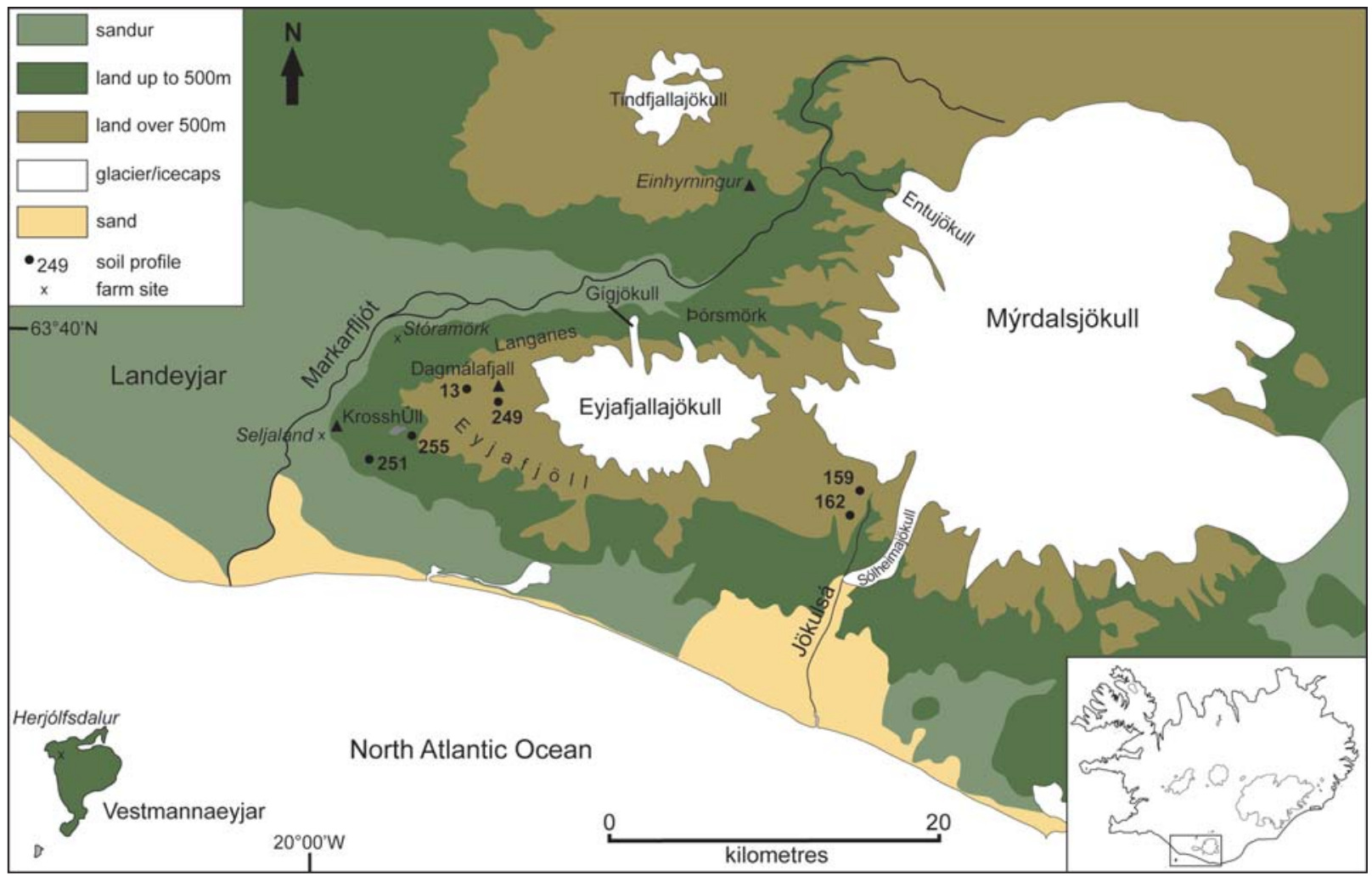


2007). Soil erosion is a significant issue today and has been a significant issue in the past, as it is likely to have contributed to the early (pre- $14^{\text {th }}$ century) abandonment of farms sites in the Pórsmörk district (Sveinbjarnardóttir 1982, 1992), particularly as it occurred in combination with widespread vegetation change and a loss of woodland that necessitated active woodland conservation measures to ensure the continued local production of charcoal (Fig. 7; Dugmore et al. 2006). Rofabard erosion forms are striking in the area (Fig. 2). They are formed in vegetated areas of thick but non-cohesive Andisols, which are undermined beneath the root mat, creating bare soil escarpments (Arnalds 1999). As these slopes erode, they create areas stripped of soil, and leave isolated upstanding islands of surviving vegetation and soil, surrounded by semi-barren exposures of the sub-soil surface. Various erosive processes are active on rofabards, but water erosion (especially when driven by strong winds), direct wind erosion, and freeze-thaw action are the most effective for moving sediment. These processes are further aided by trampling of sheep that use rofabards for shelter.
Other erosion forms common in the area are spot or localized erosion within vegetated areas, and more extensive exposures of gravels and sand.

\section{Tephrochronology around Eyjafjallajökull}

The study area has been frequently covered by fallout from nearby volcanic systems, resulting in the formation of at least 78 discrete tephra layers (Figs. 8, 9; Dugmore 1987). The tephra layers exhibit a range of macroscopic features that reflect major differences in geochemical composition, eruption mechanism, total tephra volume, and principal directions of fallout (Self and Sparks 1981). Icelandic tephra layers are primarily composed of vesicular glass shards (Larsen 1981). Layer colours vary from white through yellows, reds, browns, and greys to black (Thorarinsson 1967). Tephra layers may be uniform in colour or composed of characteristic mixes of different coloured pumices, crystals, or lithic fragments. Around Eyjafjallajökull, tephra particle sizes range from gravel grade to silt; particle shapes include a range of vesicularities and both rounded and elongated grains. The thickness

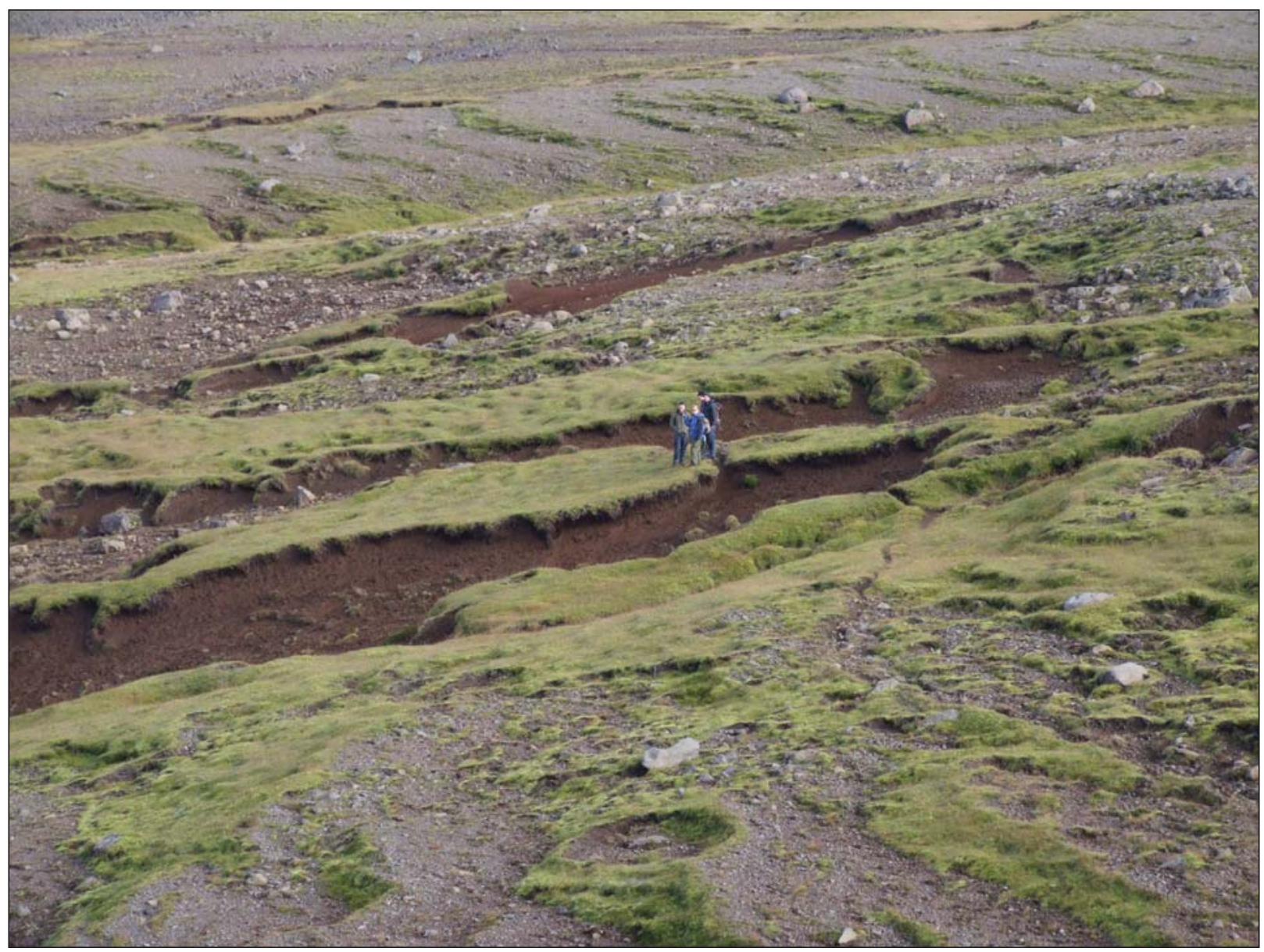

Figure 6. Soil patches on slopes in the broad upper valley of Seljalandsá at ca. $650 \mathrm{~m}$ altitude, $2 \mathrm{~km}$ SW of profile 249 (Fig. 5). In this sheltered area, some soils survive that have benefited form profile thickening as they have received sediment from neighboring eroding areas. Outside the sheltered areas, the Landnám tephra is generally within $0.5 \mathrm{~m}$ of the base of the soil. Photograph (C) Andrew J. Dugmore. 
of individual tephra layers varies from ca. 1-500 mm (Dugmore 1987, Einarsson et al. 1980). The rapid accumulation of aeolian sediments throughout post-glacial times has generally produced a clear stratigraphic separation of individual tephra layers, including deposits that may differ in age by less than two decades.

The timing of eruptions or tephra falls can be recorded in historical sources (e.g., Thorarinsson 1967), correlated to annually laminated icecore records (e.g., Grönvold et al. 1995), or dated using radiocarbon measurements on associated organic material (e.g., Kjartansson et al. 1964). The tephrochronology used here is based on the regional framework established by a number of workers (Buckland et al. 1991; Dugmore 1987, 1989; Einarsson et al. 1980; Halflidason et al. 1992; Haraldsson 1981; Larsen 1981, 1982, 1984, 1996; Thorarinsson 1944, 1967, 1975). Tephras from the volcanic systems of Katla, Hekla, Eyjafjallajökull, Torfajökull, and Veiðivötn have been identified in the study area, and other layers provide additional local isochrones even though their source has not been firmly identified, e.g., Layers Hr, Ho, T, and St of Dugmore (1987). The high quality of the tephra record is enhanced by the presence of tephra layers close to the stratigraphic location of important environmental changes.

Of particular relevance to this study, the Landnám tephra, with an ice core date of AD $871 \pm 2$ (Grönvald et al. 1995), effectively marks the start of Norse settlement. Further temporal control on the Landnámsöld or "Age of Settlement" AD 870-930 is given by the Katla tephra of ca. AD 920 (K 920) (Haflidason et al. 1992), and the Eldgjá tephra of ca. AD 935 (E 935) (Zielinski et al. 1995). In addition, other tephra horizons used in this study have been historically dated to AD 1300, AD 1341, AD 1357, AD 1500, AD 1510, AD 1721, AD 1755, AD 1821, AD 1823, AD 1918, and AD 1947 (Einarsson et al. 1980; Larsen et al. 1999; Thorarinsson 1967, 1975). In prehistory, the tephra layer SILK-YN has been dated using 22 radiocarbon samples to give a combined date of $1676 \pm 12$ ${ }^{14} \mathrm{C}$ yr BP, or ca. AD cal. 400 (Dugmore et al. 2000). In addition, the tephras SILK-UN, Layer L, and Layer $\mathrm{K}$ have all been dated with single radiocarbon dates and used to constrain prehistoric rates of landscape change (Dugmore 1989).

Tephras may be grouped to define broader cul-

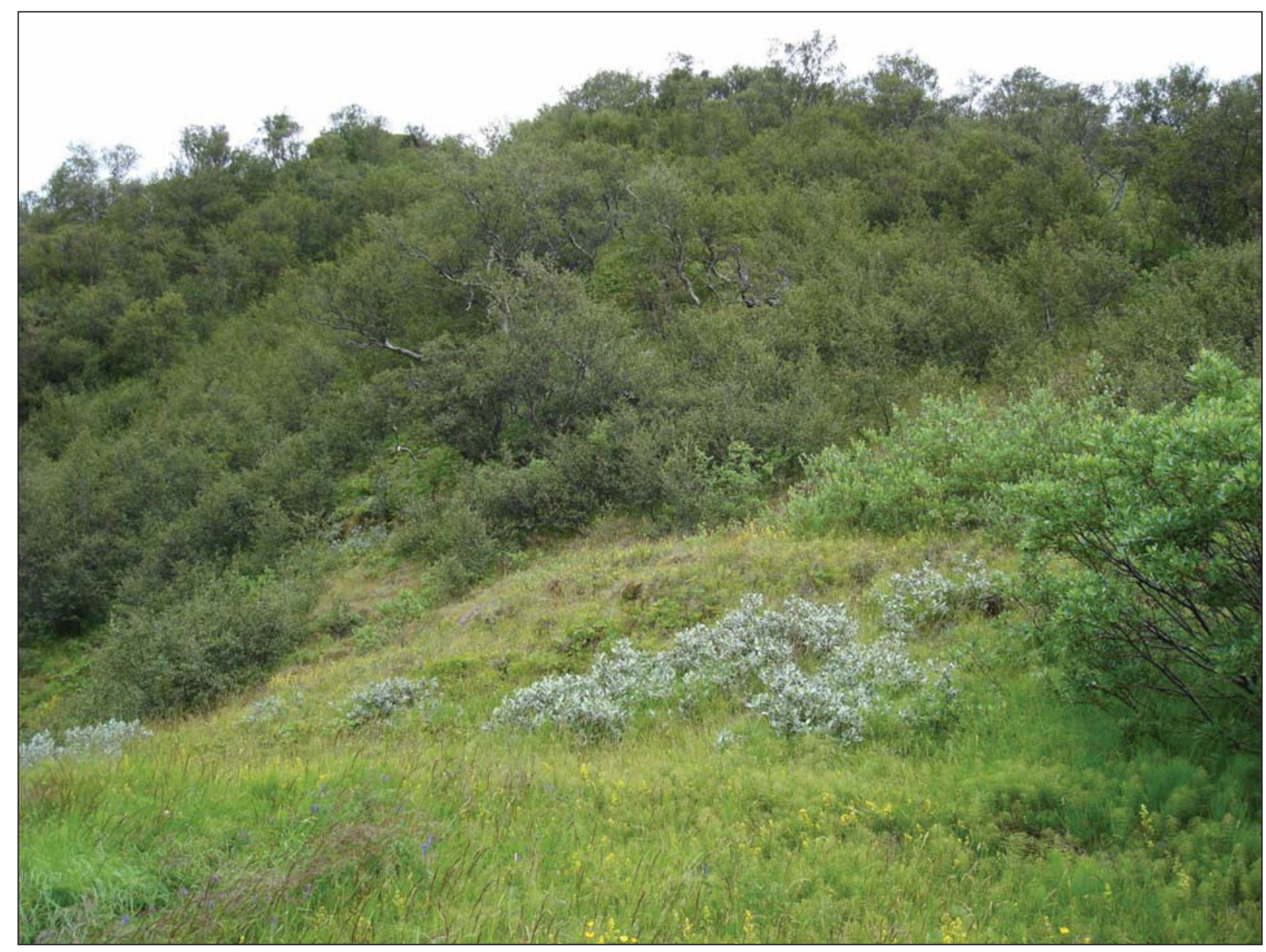

Figure 7. A part of the woodland in Pórsmörk (Fig. 5). In the foreground, the grassy mound and meadow marks the site of the farm of Húsadalur, one of the settlement sites that have been intermittently occupied in the region. In the background, the dense growth of Betula pubescens was once coppiced for charcoal. Photograph @ Guðrún Gísladóttir. 
turally and environmentally significant phases and assess change over clearly defined periods of time. Firstly, the stratigraphy below the Landnám tephra preserves a record of landscapes without human impact. Secondly, the Landnám tephra combined with either K 920 and/or E 935 can be used to assess the initial Norse colonisation and the first generation of settlement. Thirdly, the stratigraphy bounded by K 920 or E 935, and the Hekla tephra of AD 1510 (H 1510) encompasses the changing conditions of the "Medieval Warm Period" (e.g., Jiang et al. 2005, Massé et al. 2008, Sicre et al. 2008). Fourthly, H 1510 and the Hekla tephra of AD 1947 (H 1947) bound the sedimentary record of the major cold phases of the "Little Ice Age" as defined by glacier advances (Bradwell et al. 2006, Casley and Dugmore 2004). Finally, H 1947 provides an unambiguous modern stratigraphic marker that effectively coincides with the first complete aerial survey of Iceland in 1946.

\section{Models of soil erosion}

A wider conceptual framework of historical soil erosion is provided by the altitudinal model of Dugmore and Buckland (1991) and conceptual model of stress, dynamics, and thresholds of the ecosystem by Gísladóttir (2001). The central argument is that anthropogenic soil erosion induced by grazing first developed in upland, ecological marginal areas, and then spread to lower, initially less marginal areas because of biomass utilization driven by a combination of stocking levels, loss of grazing land, reduced growing seasons, and changing land-management practice. Different factors are thought to come into play with differing intensity at different times, but the net result is continued erosion of a decreasing total area of soil.

Some key questions remain unanswered. Crucially, there is the apparent inconsistency between modern rates of soil-cover loss and the historical rates needed to explain cumulative soil erosion since Landnám. Fridriksson (1988, 1995) has measured modern rofabard retreat rates of $16 \mathrm{~cm} \mathrm{yr}^{-1}$ in the Hekla district of southern Iceland, and extensive measurements by Fridriksson and Gudbergsson (1995) of rates of erosion-front movement have ranged from 1-26 $\mathrm{cm} \mathrm{yr}^{-1}$. Arnalds (1999) has estimated an overall loss of Andosols cover due to rofabard erosion to be 43,200 $\mathrm{km}^{2}-53,200 \mathrm{~km}^{2}$ since the time of settlement. These areas are presently characterized by rofabard areas, deserts, and areas where sand encroachment and rofabard retreat are the major processes. The temporal variations of the soil cover are, however, missing in those figures. Arnalds (1999) estimated that the 232 ha $\mathrm{yr}^{-1}$ soil

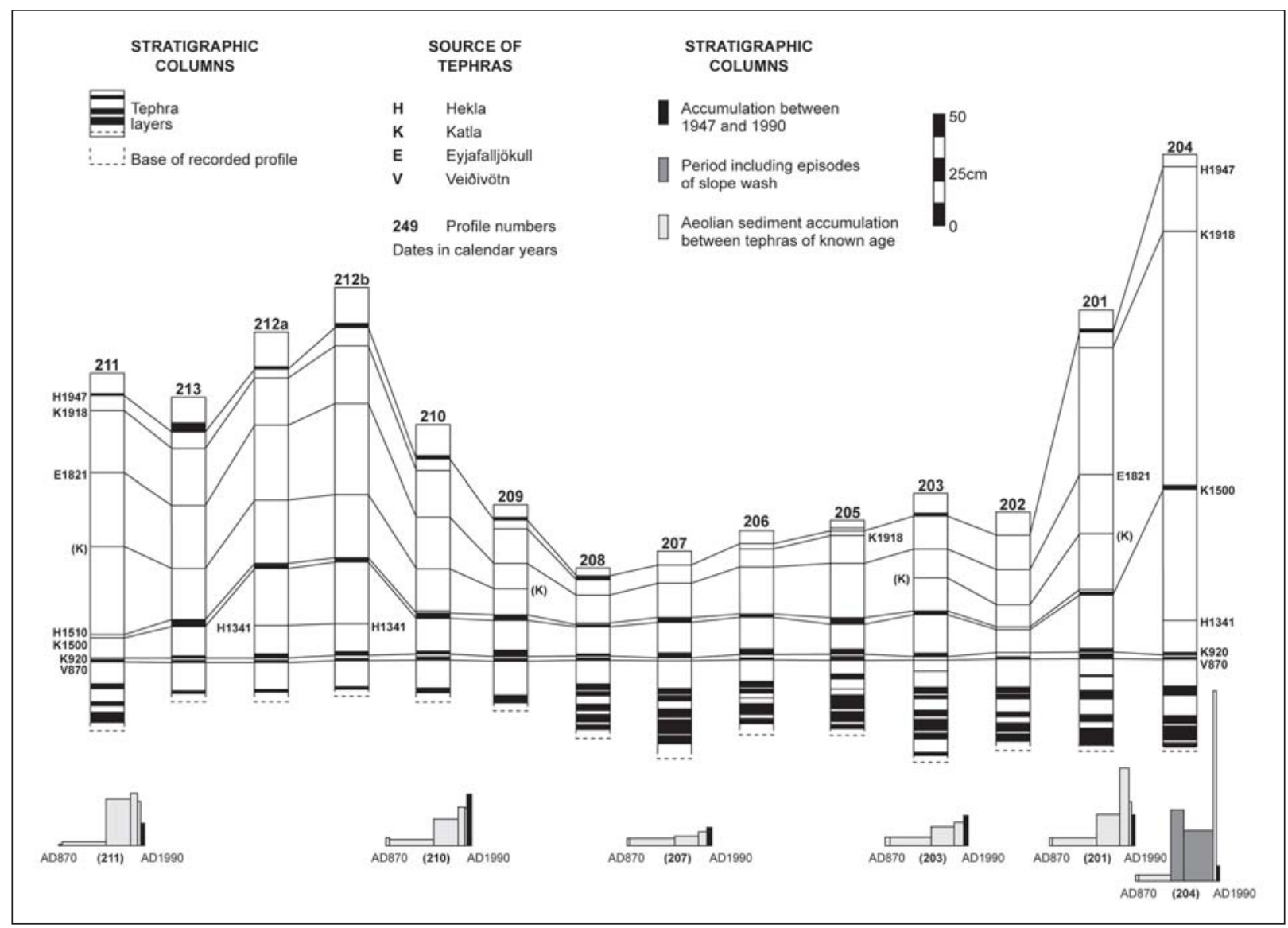

Figure 8. Post-Landnám tephra stratigraphy and sediment accumulation rates calculated for selected profiles at Kroshóll, Seljaland (location shown on Figure 5). 
loss around present rofabards had reduced by one order of magnitude because extensive areas have become desertified, leaving the rofabards as remnants of previously soil-covered area. Crucially, this implies a reducing rate of loss of soil area to erosion

In contrast, tephrochronological studies indicate temporal change in aeolian activity and intensification after the $17^{\text {th }}$ century. Sigurbjarnarson (1969) showed sediment influx during the $12^{\text {th }}$ and 13th centuries and again during the "Little Ice Age" in the $17^{\text {th }}-19^{\text {th }}$ centuries, and Thorarinsson (1981) showed that total sediment accumulation rates accelerated into modern times. Peaks of accumulation in early Settlement times, especially at higher altitude and interior sites, are locally significant, but in absolute terms they are significantly less than the later rates reached elsewhere (Dugmore and Buckland 1991,
[1999

IN LIT.

CITED. WHICH IS CORRECT?] Dugmore et al. 2000). In addition, offshore records show a marked increase in the terrestrial sediment influx after the 17th century (Jennings et al. 2001). Thus, in contrast to modern data on changing landcover, sediment accumulation rates would seem to imply increasing rates of soil loss due to erosion.

The Dugmore and Buckland (1991) altitudinal model of cascading impacts can be refined using both data from individual soil profiles, and closely spaced groups of profiles to tackle some key questions about landscape change in Iceland. Firstly, have the rates of soil-cover loss changed in recent times? Secondly, have sediment-flux rates changed in recent times. Finally, is it possible to reconcile estimates of changing soil area and sediment-flux data?

\section{Results}

\section{Soil profiles and measures of soil erosion}

Stratigraphic sections in aeolian soils have been measured at over 200 sites around Eyjafjallajökull, and detailed field mapping is supported by geochemical analyses and radiocarbon dating (Dugmore 1987, Dugmore and Buckland 1991, Dugmore and Erskine 1994, Dugmore et al. 2000, Larsen et al. 1999). The distribution of tephra has been determined from exposures $>50 \mathrm{~cm}$ wide in open sections where the stratigraphy of profiles up to $12 \mathrm{~m}$ deep was recorded to a precision of $\pm 2 \mathrm{~mm}$.

Individual soil profiles have been assessed using tephrochronology to determine four key data sets: the rates and types of sediment accumulation for clearly defined periods of time (Fig. 8), the geometry of the tephra layers, and the microtopography of the land surface when the tephra was deposited.

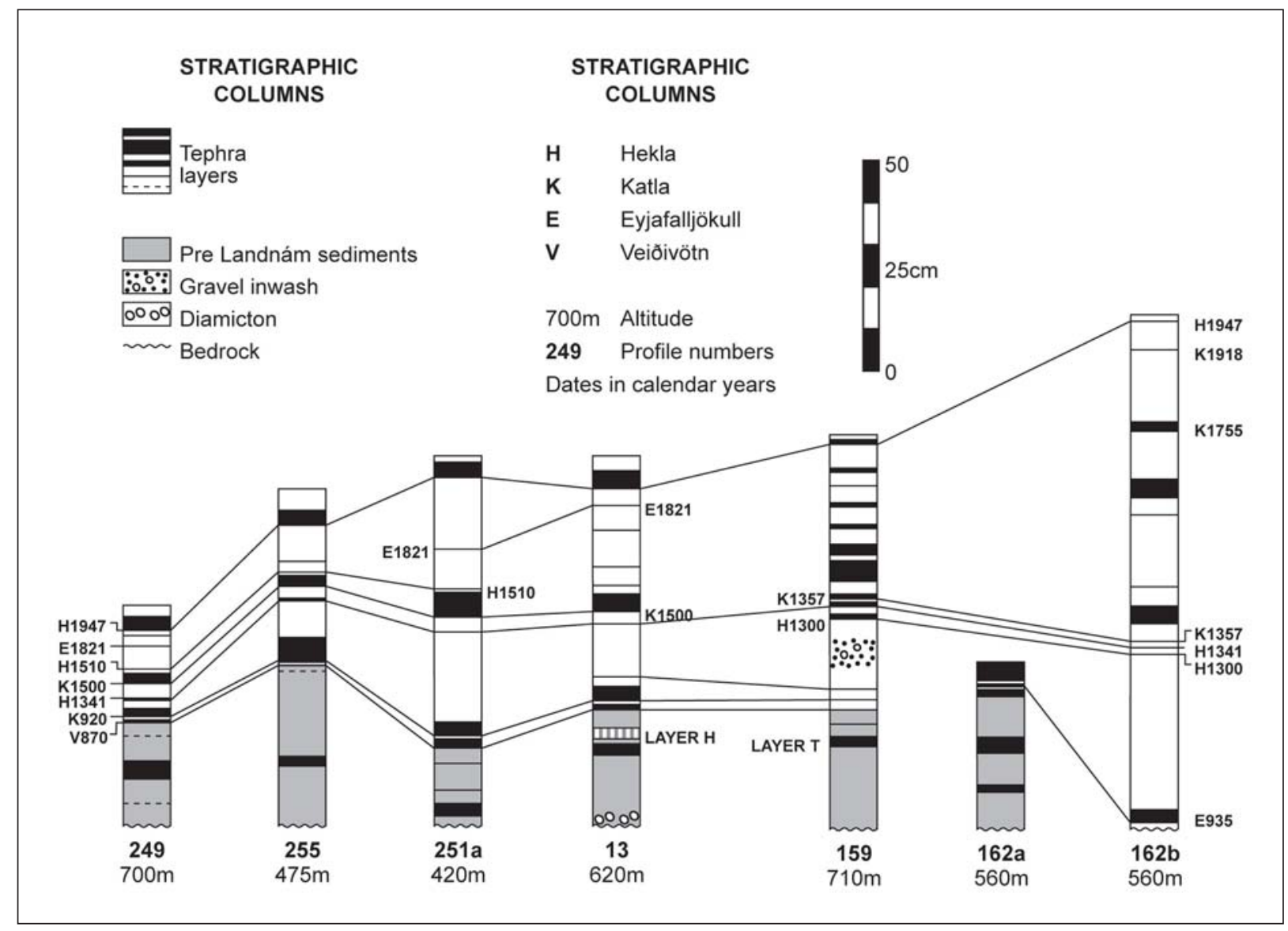

Figure 9. Tephra stratigraphy in upland profiles located on Figure 1. At the time of settlement soil profiles at these sites were less that $50 \mathrm{~cm}$ deep (Fig. 6). 
In addition, total profile thickness at landnám was determined as an additional factor, with both distinct geographical variation and important implications for the development of soil erosion in historical time (Fig. 9). Accumulation rates and sediment type indicate the nature and intensity of erosion (Fig. 10), and the geometry of the tephras indicate whether sources of sediment, and hence areas of erosion, are local (from $<10 \mathrm{~m}$ ) or regional (from $>1 \mathrm{~km}$ ) (Dugmore and Erskine 1994). It is assumed that when sediment accumulation rates are similar between closely spaced profiles, the sources of aeolian sediment must
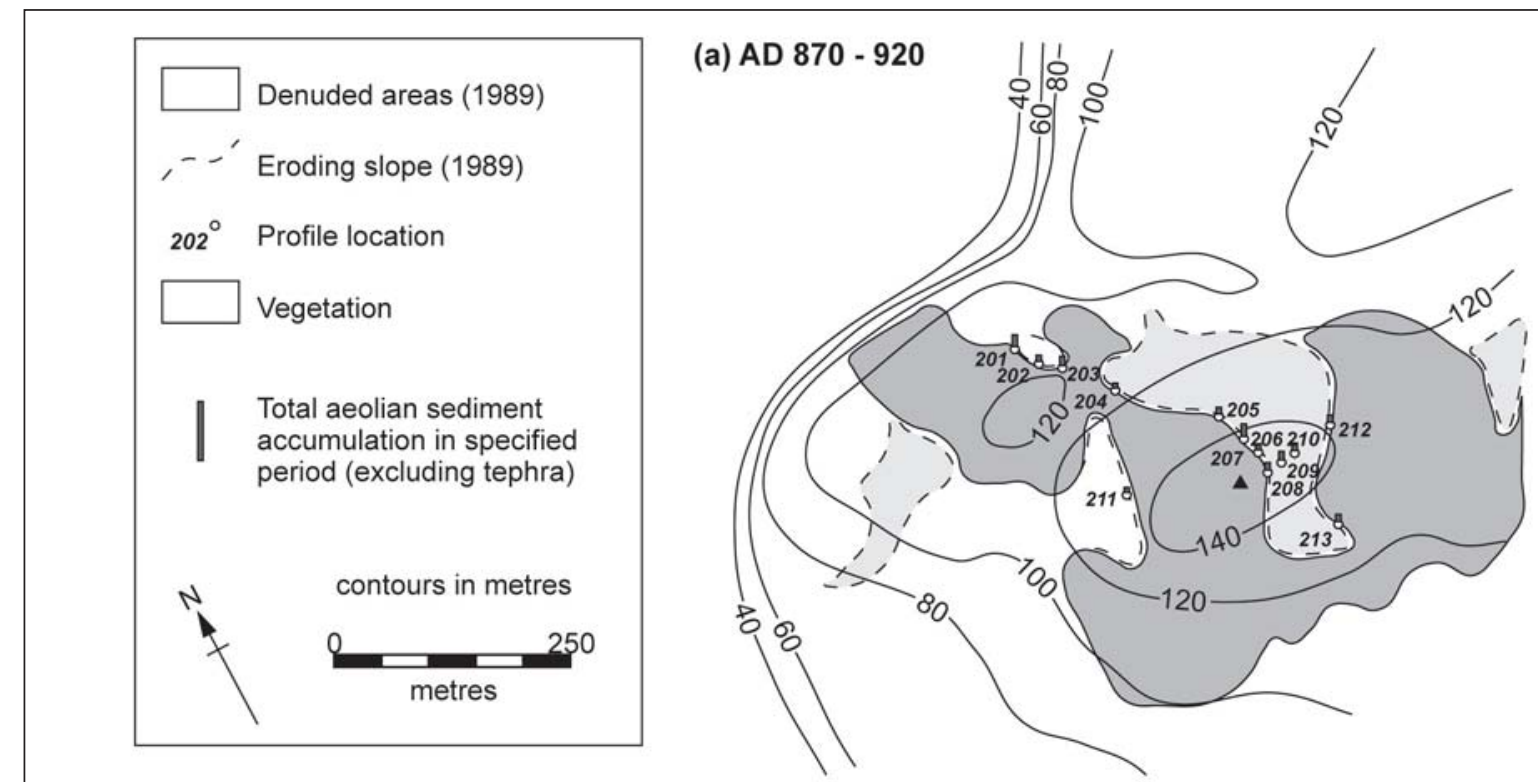

(b) AD 920 - 1510

(c) AD 1510 - 1947

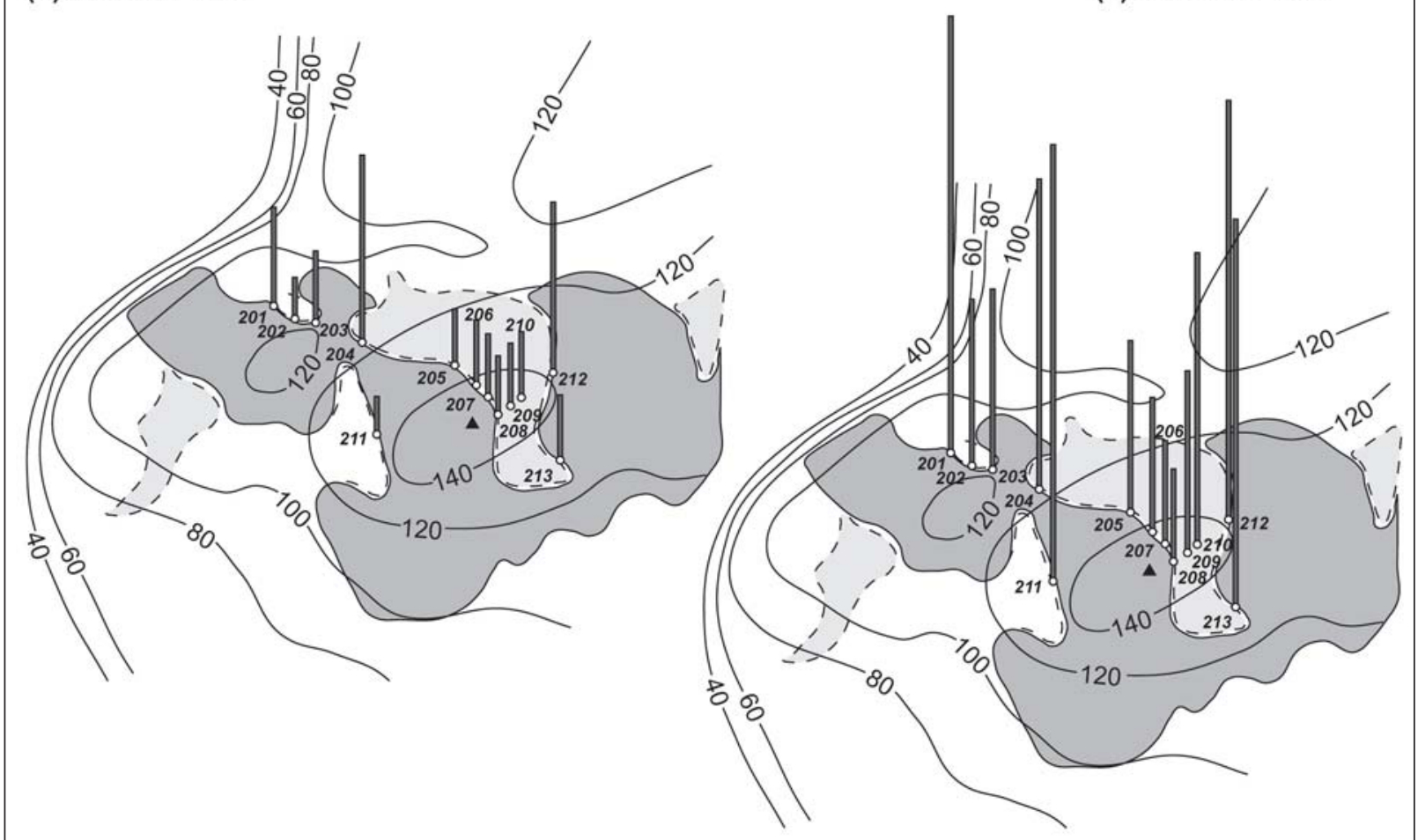

Figure 10. Variations in aeolian sediment accumulation at Kroshóll, Seljaland for three time periods: (a) AD ca. 870-920 (ca. 50 yr), (b) AD ca. 920-1510 (ca. 590 yr), and (c) AD 1510-1947 (437 yr). Although the period AD 1510-1947 is less than three quarters of the period AD ca. 920-1510, sediment accumulation rates and local variability are far greater, a probable consequence of the development of local sediment sources. 
lie outside the immediate area. For this situation to change to localized, large-scale variation in accumulation, local sources of aeolian sediment must have developed from which the wind could move sediment over short distances. Data are presented in the form of summary diagrams and maps (Figs. 8-11). These focus on both reconstructions of specific years, such as AD 1341 and AD 1821 (Fig. 11), as well as changes over longer periods, such as the initial settlement period between AD 870-920, AD 920-1510, and AD 1510-1947 (Fig. 10).

\section{Rates of denudation}

The stratigraphic data at Krosshóll indicates two periods when breaks first developed in vegetation cover (Figs. 8, 12). The very earliest sign of localized breaching of the vegetation cover is the presence of slope-washed gravels in profile 204 (Fig. 8) that occurs immediately above the Hekla 1341 tephra. If erosion started at the crest of the slope above pro- file 204 soon after AD 1341, then it has propagated c.130 $\mathrm{m}$ in c. $650 \mathrm{yr}$, indicating an overall rate of $20 \mathrm{~cm} \mathrm{yr}^{-1}$ (Fig. 10). This rate is consistent with the modern estimates of Fridriksson $(1988,1995)$ and Fridriksson and Gudbergsson (1995).

Increased variability between the 13 profiles on Krosshóll suggests a second and more extensive phase of local erosion developed after 1510 (Fig. 10). In this area, modern rofabards are separated by cross-slope distances on the order of $200 \mathrm{~m}$, which, given widespread local AD vegetation breaching post 1510, would also suggest an average eroding face retreat over the following $440 \mathrm{yr}$ of ca. $20 \mathrm{~cm} \mathrm{yr}^{-1}$ (Fig. 10).

\section{Sediment fluxes and an improved model of land- scape change.}

In order to synthesize the data from over 200 profiles, we have refined the altitudinal model of soil erosion by adding a conceptual model of

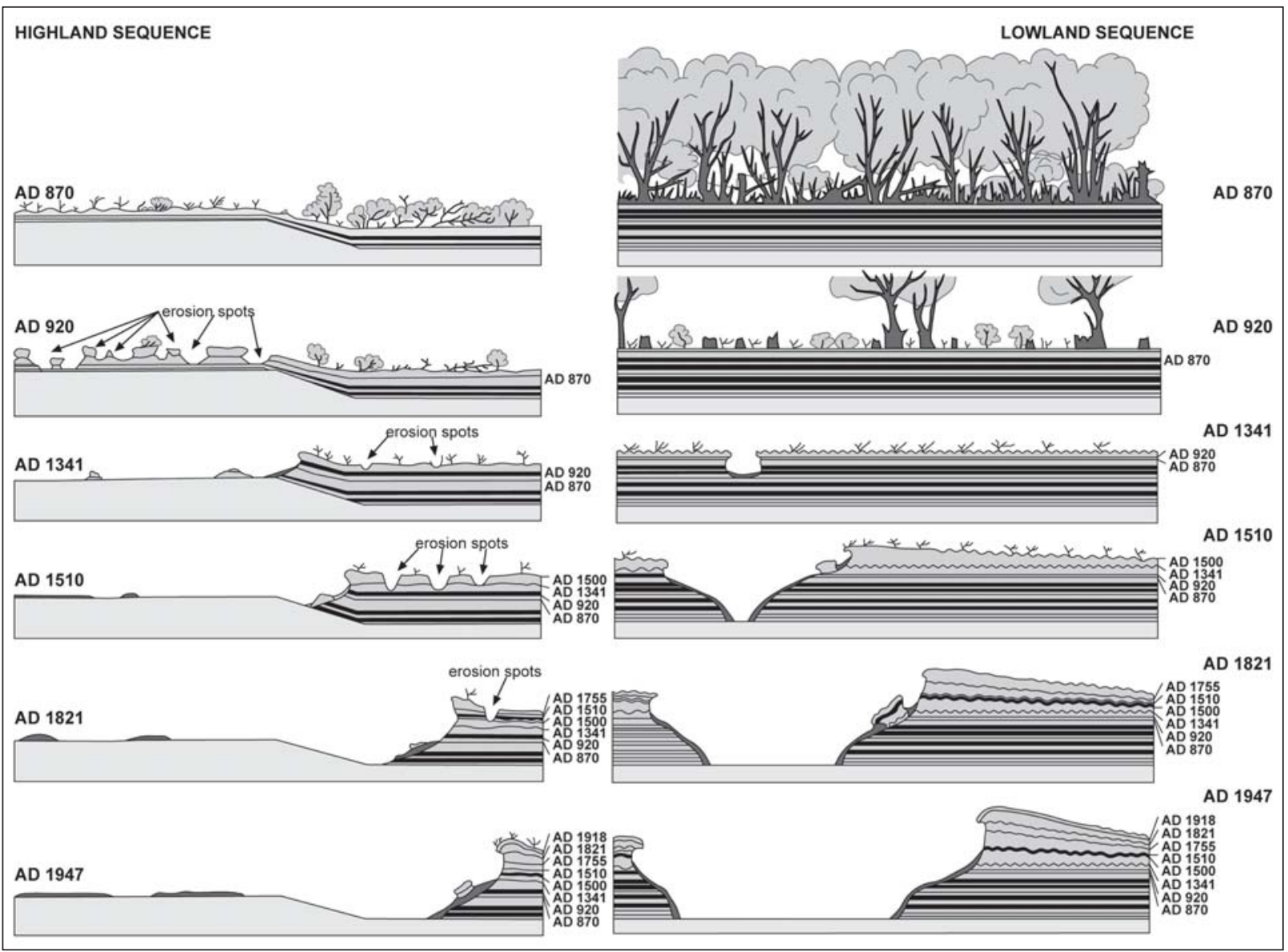

Figure 11. Reconstructions of landscape change Seljalandsheiði A.D. 870-1947 in the lowland within the pre-Landnám woodlands, and in the highland above the natural tree line at Landnám. Each cross section is drawn at the time of a tephra fall. The land surface at the time of the deposition of the landnám tephra (ca. AD 870) became a layer below the surface in 920. Prehistoric soils contain numerous tephra layers illustrated by solid horizontal lines (Fig. 3). Woodland cover at landnám is likely to have been dense, as the island lacked terrestrial herbivores. Erosion spots began first in the highlands (ca. AD 920) and appeared at lower elevations later (AD 1341) when thufur (frost hummocks) formed in the surface and were mantled by subsequent tephra falls. The 3-D geometry of the tephra layers changes as eroding slopes develop because greatest sediment deposition occurs immediately downwind of the sediment sources. 
changed vegetation pattern, and linked maps and representations of soil thickness and sediment flux across the landscape (Fig. 13). The patterns and progress of vegetation change and soil erosion and the resulting sediment flux may be governed by three key factors: contrasting sensitivities to the breaching of vegetation cover, contrasting depths of sediment in uplands and lowlands, and the rate of development of rofabards.

\section{Discussion}

Upland heaths are likely to have been the most sensitive areas to grazing impacts in the early historical period in Iceland (AD 920 and AD 1341; Fig. 11). Here the growing season is shorter than the lowlands, and grazing may easily extend beyond the start and after the end of the summer biomass production season (Simpson et al. 2001). Some upland areas would not have been able to support sustainable year-round grazing at the time of the Norse settlement, and these areas would have expanded with the subsequent episodes of climatic cooling. Unsustainable grazing could have caused changed patterns of species abundance where species intolerant to trampling and grazing increased [??] and the plant community became less able to withstand erosion leading to creation of many breaches in the vegetation cover. These changes are likely to have developed in heathlands where the micro-scale pattern of plants form a heterogeneous pattern and where thufur or turf hummocks characterize the land surface (Fig. 11). Thufur are formed by a vegetated mound of soil, the top surface of which is sensitive to disruption by freeze-thaw cycles and grazing pressure (Webb 1972). The plant communities that characterize these environments consist of a mosaic consisting of different species of mosses, dwarf shrubs, grasses, and herbs, out of which mosses (e.g., Racomitrium lanuginosum [racromitrium moss]) and dwarf shrubs (e.g., Empetrum sp.) are the least tolerant to trampling and grazing (Gísladóttir 1998).

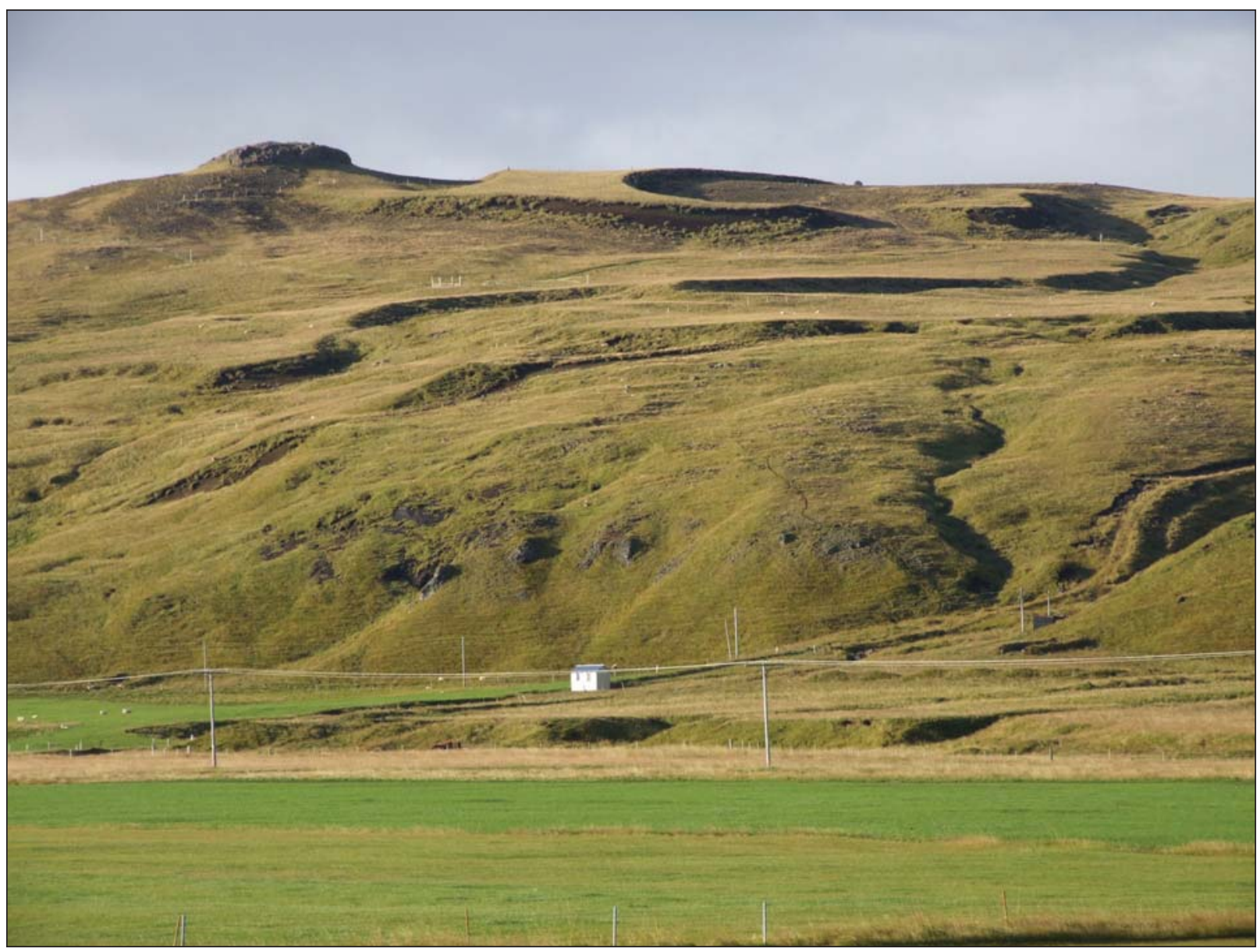

Figure 12. Kroshóll in South Iceland (Fig. 5) viewed from the South. The rocky knoll on the skyline is the location of the 207-m spot height (Figs. 5, 10). Deep soils that once covered the whole ridge have been reduced by rofabard erosion, the extent of which is shown by the steep semi-vegetated slopes that surround the remaining upstanding areas of deep soils. Vegetation cover has regenerated on the lower slopes stripped of their deep soils. The heavily managed home fields of the Seljaland farms can be seen in the foreground. Short, steeper slopes mark the boundary between sandar (river flood plain) in the foreground and truncated low angled fans at the foot of the main escarpment (site of the small house for a water turbine). Photograph (c) Andrew J. Dugmore. 


\section{(A) Pre Landnám c. AD 400}
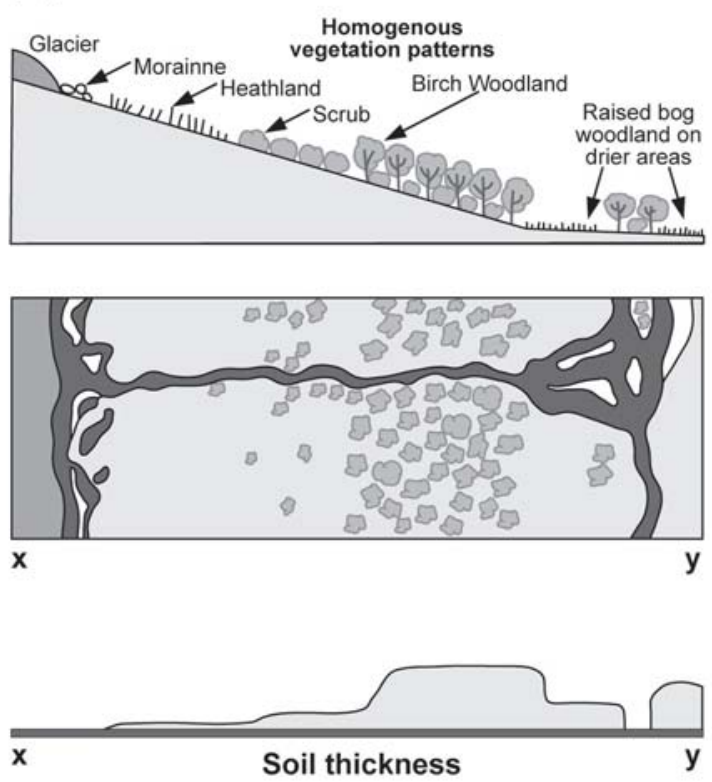

(B) AD 920 - 1510
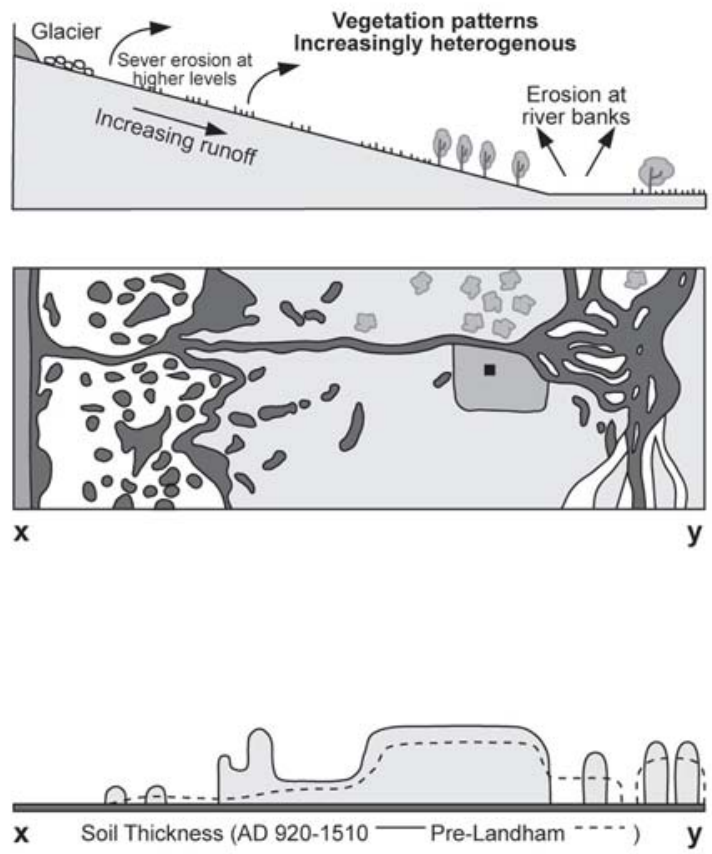

\section{(C) AD 1510 - 1947}
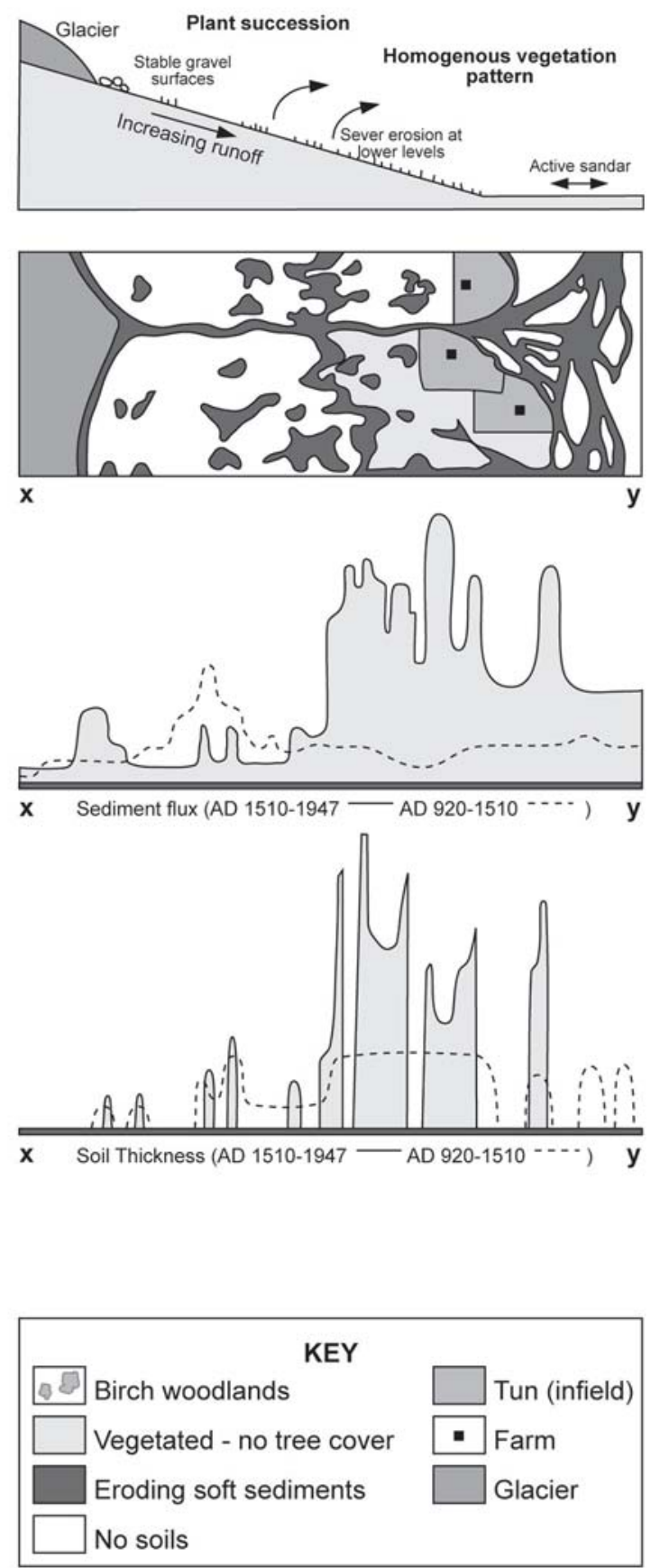

Figure 13. Models of landscape change: (A) pre-Landnám ca. A.D. 400, (B) ca. A.D. 920-1510, and (C) $1510-1947$ A.D. $\mathrm{x}-\mathrm{y}$ is a cross section illustrating soil thickness from the upland ice margin to the valley floor. In (A), shallow soils are generally associated with upland heaths (although there may be deeper sediment accumulations in sheltered areas [cf Fig. 6]). At lower altitudes, soils will tend to be thicker as they will be older and will have benefited from sediments moving down slope. The stepwise changes in soil cover on the floodplain have been created by episodic movements of the river channel. In (B) (AD 920-1510), change is illustrated by the two idealized cross sections of soil thickness (a dashed line for Stage A, and a solid line for Stage B). Areas that have maintained a vegetation cover will have also experienced profile aggradation. Anomalously great sediment accumulations are proposed to have taken place in stable areas close to sources of eroding soil. In (C) (AD 1510-1947), two sets of cross sections are shown, one for soil thickness and one for sediment flux, a representation of the amount of sediment transported across the landscape. Dashed lines represent Stage B, and solid lines represent Stage C. The rate of movement of sediment is proposed to peak close to eroding soils and to have been at its greatest where the soil cover was at its deepest. 
Those sensitive plant groups are frequent on top of the thufur. The combination of this species pattern and thufur formation in the heathland makes it an extremely sensitive environment (Gísladóttir 2001). The presence of thufur in past landscapes is shown by the form of tephra layers within the soil profile
(Dugmore and Buckland 1991), and the dimensions of the fossil structures are similar to those of today, ranging in size from 20-50 cm in height and 50-200 $\mathrm{cm}$ in diameter (Thoroddsen 1914). With vegetation breaks occurring on thufur, a dense, meter-scale patchwork of spot erosion could form, which then

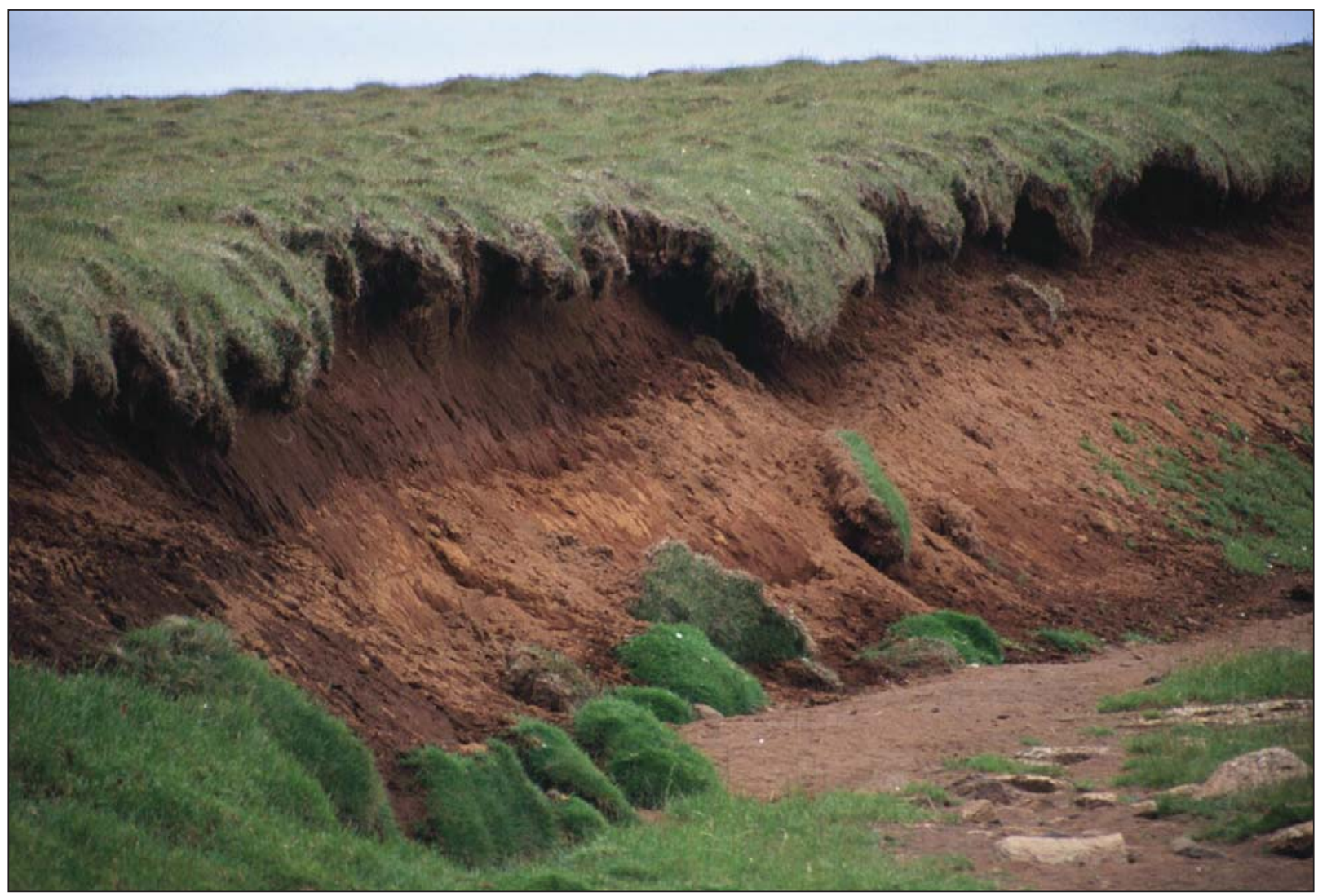

Figure 14. An eroding soil showing the form of the slope characterised by the $20^{\text {th }}$-century profile of Figure 15 . Erosion of the exposed sediment undercuts the turf causing collapse. Once they have formed, comparatively low levels of grazing can help to maintain erosion on these slopes through browsing and trampling, particularly as sheep seek out the overhangs of these eroding slopes for shelter. Photograph @ C Guðrún Gísladóttir.

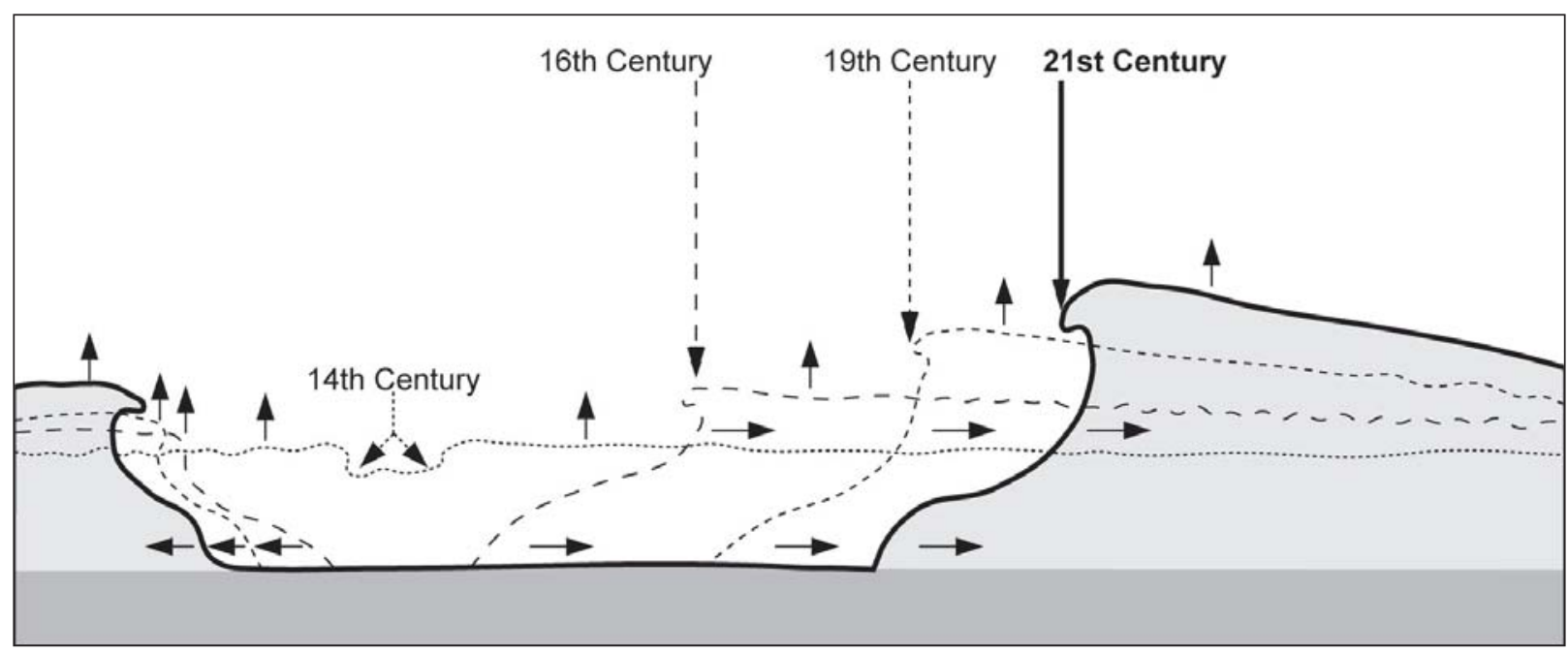

Figure 15. Lowland rofabard development 14th-20th century AD Once rofabards have developed, small-scale lateral movements of the eroding face can result in large-scale sediment mobilization, a process enhanced by the thickening of the surviving soil profile (Fig. 14). 
gradually developed into larger areas of active soil erosion and resulted in deserted areas. Rofabards could form at the edges of deserted areas and thicker soils. Erosion of these exposures at a similar rate to the historical development of rofabards at Krosshóll (ca. $20 \mathrm{~cm} \mathrm{yr}^{-1}$ ), or even the lower range of modern rates measured elsewhere (1-10 $\left.\mathrm{cm} \mathrm{yr}^{-1}\right)$, could then result in the rapid stripping of large areas of soil. This process could explain large-scale spatial change, without requiring the rapid ( $>100 \mathrm{~cm} \mathrm{yr}^{-1}$ ) movement of individual eroding faces.

The denudation of large areas of sensitive upland soils may have only had a comparatively modest overall impact on regional sediment flux rates because of the shallow soil profiles involved (Fig. 9). This situation would have changed when large-scale erosion developed within the deeper lowland soils (Figs. 11, 12). Rofabards formed within the old forest zones may only erode at a similar rate to soil exposures in the uplands, but this process would involve soils at least 2-5 m thick, and consequently result in the movement of large volumes of soil (Figs. $14,15)$. Initial breaches in the vegetation cover at lower, ecologically less-marginal altitudes seem to have developed later in historical time, and been more widely spread apart, as the areas of surviving vegetation cover tend to be substantial 10-100-m scale patches (Fig. 9). Here the change in vegetation pattern varied from the more-marginal upland areas (Fig. 11), making the lowlands more resistant to vegetation breaches. With similar rates of erosion at individual soil exposures, a less-dense patchwork of rofabards will produce a slower overall loss of soil cover. As a result, there is no need to invoke radical changes in the rate of erosion at individual soil exposures to explain both changes in soil cover as well as aeolian sediment flux in the south of Iceland.

\section{Wider implications}

Our refined model of soil erosion highlights two particularly important processes: factors that trigger the development of individual erosion faces, and those that control the propagation of the erosion. Triggering factors for soil erosion must be closely related to the changing status of the vegetation cover, and so to the net effect of grazing. The impact of grazing will be primarily determined by rangeland-management practices, such as livestock type, stocking levels, and the management of day-today grazing patterns, and its overall annual duration. Rangeland management will also be influenced by the availability of fodder collected elsewhere, such as hay, and the potential to feed stock through the winter and spring. In addition, the past will exert a significant influence, as the cumulative landscape history will play a key role in determining biomass productivity and sensitivity to change; for example, past land-management decisions may have modified soil profiles and altered the composition and nature of the vegetation. Breaches in the vegetation cover will occur more easily in heterogeneous plant communities where species are intolerant to stress and where formation of thufur has formed due to a substantial mismatch between biomass production and the grazing offtake. It may also be triggered by catastrophic events such as freak weather, or volcanic activity and tephra deposition.

Therefore, we would see land management, through both its long-term impacts and response to short-term environmental change, as playing the critical role in determining the timing and location of vegetation-cover disruption, and the triggering of soil erosion. However, crucially, sensitivity to this critical threshold may be altered by both long- and short-term climatic changes.

Once soil erosion has been initiated, it may be sustained and propagated as much by climatic factors as land use, because a lower intensity of grazing is required to maintain exposures of bare soil than is needed to break an established vegetation cover. In addition, key factors in determining the erosion rates of bare soil slopes include the purely climatic factors of needle ice formation, rainfall, and wind. As differing combinations and intensities of precipitation, wind, and temperature can vary rates of erosion, it is possible that distinct climate signals are embedded within the overall rate of soil erosion and related sediment accumulation. If the role of management practice can be clearly defined, aeolian sediment accumulation in southern Iceland over the last 1200 yr may be shown to contain a proxy record of climate change.

\section{Conclusions}

There are three key factors in the development and geomorphological impact of soil erosion in southern Iceland: the density of breaks in vegetation cover, the rate of soil erosion at these breaks, and the depth of the eroding soil profile. Rapid denudation is associated with a high density of vegetation breaches, which have tended to occur early in historical time in upland heaths where soil profiles were shallow at the time of settlement (generally $<0.5 \mathrm{~m}$ ). Despite a widespread change in soil cover, the overall impact on sediment fluxes was not as great as the later but less spatially extensive erosion of deeper soils (generally $>2 \mathrm{~m}$ ). Modern erosion is characterized by a lower density of eroding slopes and the exposure of deep soil profiles, so while the overall rate of loss of soil cover is now well below the historical average, the impact on sediment fluxes is greater because of the volumes of soil involved. Land-management decisions played a primary role 
in triggering soil erosion, but climate may substantially determine the subsequent soil erosion rates.

\section{Acknowledgments}

This work has been supported by grants from the Leverhulme Trust, as part of the landscapes-circum-landnám program, the UK Natural Environmental Research Council, the University of Iceland Research Fund, and the US National Science Foundation Office of Polar Programs Arctic Social Sciences (grant number 0732327 as part of the International Polar Year Humans in the Polar Regions project "IPY: Long Term Human Ecodynamics in the Norse North Atlantic: Cases of sustainability, survival, and collapse”). Paula Milburn and Jeanette Yates provided fieldwork assistance, and cartography was undertaken by Gerry White, University of Edinburgh. We gratefully acknowledge the support of the people of south Iceland, in particular Kristján Ólafsson of Seljaland and Rósa Aðalsteinsdóttir of Stóramörk

\section{Literature Cited}

Amorosi, T., P.C. Buckland, A.J. Dugmore, J.H. Ingimundarson, and T.H. McGovern. 1997. Raiding the landscape: Human impact in the Scandinavian North Atlantic. Human Ecology 25(3):491-518.

Aradottir A.L., O. Arnalds, and S. Archer. 1992. A model for land degradation. (In Icelandic.) Græðum Ísland (Yearbook of the Soil Conservation Service) 1:13-31.

Arnalds, A. 1987. Ecosystem disturbance and recovery in Iceland. Arctic and Alpine Research 19:508-513.

Arnalds, O. 1999. The Icelandic rofabard soil erosion features. Surface Processes and Landforms 24:1-12.

Arnalds, O. 2004. Volcanic soils of Iceland. Catena 56:3-20.

Arnalds, O., E.F. Thorarinsdottir, S. Metusalemsson, A. Jonsson, E. Gretarsson, and A. Arnason. 2001a. Soil erosion in Iceland. (English translation of original Icelandic publication from 1997.) Soil Conservation Service and Agricultural Research Institute, Reykjavik, Iceland. $121 \mathrm{pp}$.

Arnalds, O., F.O. Gisladottir, and H. Sigurjonsson. 2001b. Sandy deserts of Iceland: An overview. Journal of Arid Environments 47:359-371

Bergthorsson, P. 1996. Temperature and vegetation. (In Icelandic with English abstract.) Icelandic Agricultural Sciences 10:141-164

Bjarnason, H. 1974. The history of Iceland and woodland destruction. (In Icelandic.) Ársrit skógræktarfélags Íslands 1974:30-43.

Bradwell, T., A.J. Dugmore, and D.E. Sugden. 2006. Little Ice Age glacier maximum in Iceland and the North Atlantic Oscillation: Evidence from Lambatungnajökull, southeast Iceland. Boreas 35:61-80.

Buckland, P.C., A.J. Dugmore, D. Perry, D. Savory, and G. Sveinbjarnardóttir. 1991. Holt in Eyjafjallasveit, Iceland: A palaeoecological study of the impact of Landnám. Acta Archaeologica 61:267-271.

Buckland, P.C., K.J. Edwards, J.J. Blackford, A.J. Dugmore, J.P. Sadler, and G. Sveinbjarnardóttir. 1995. A question of Landnam: Pollen, charcoal, and insect studies on Papey. Iceland. Pp. 245-265, In R. Butlin and N. Roberts (Eds.). Ecological Relations in Historical Times. Blackwell, London, UK.
Cas, R.A.F., and J.V. Wright. 1987. Volcanic Successions: Modern and Ancient. Allen and Unwin, London, UK.

Caseldine, C.J. 1987. Neoglacial glacier variations in northern Iceland: Examples from the Eyjafjordur area. Arctic and Alpine Research 19:296-304.

Casely, A.F., and A.J. Dugmore. 2004. Climate change and "anomalous" glacier fluctuations: The southwest outlets of Mýrdalsjökull, Iceland. Boreas 33:108-122

Church, M.J., A.J. Dugmore, K.A. Mairs, A.R. Millard, G.T. Cook, G. Sveinbjarnardóttir, P.A. Ascough, and [PROVIDE INITIALS] Roucoux 2007. Charcoal production during the Norse and early medieval periods in Eyjafjallahreppur, southern Iceland. Radiocarbon 49(2): [PROVIDE PAGE NUMBERS].

Dugmore, A.J. 1987. Holocene glacial fluctuations around Eyjafjallajökull, South Iceland. Ph.D. Thesis. University of Aberdeen, UK. 214 pp.

Dugmore, A.J. 1989. Tephrochronological studies of Holocene glacier fluctuations in southern Iceland. Pp. 37-55, In J. Oerlemans (Ed.). Glacier Fluctuations and Glacial Change. Kluwer Academic Publishers, Dordrecht, The Netherlands.

Dugmore, A.J., and P.C. Buckland. 1991. Tephrochronology and late Holocene soil erosion in South Iceland. Pp. 147-159, In J. Maizels and C. Caseldine (Eds.). Environmental Change in Iceland. Kluwer, Dordrecht, The Netherlands.

Dugmore, A.J., and C.C. Erskine. 1994. Local and regional patterns of soil erosion in southern Iceland. Münchener Geographische Abhandlungen 12:63-79.

Dugmore, A.J., A.J. Newton, and G. Larsen. 1995. Seven tephra isochrones in Scotland. The Holocene 5:257-266.

Dugmore, A.J., A.J. Newton, G. Larsen, and G.T. Cook. 2000. Tephrochronology, environmental change, and the Norse settlement of Iceland. Environmental Archaeology 5:21-34.

Dugmore, A.J., G. Larsen, and A.J. Newton. 2003. Tephrochronology and its application to Late Quaternary environmental reconstruction, with special reference to the North Atlantic islands. Pp. 173-189, In C. Buck and A. Millard (Eds.). Constructing Chronologies: Crossing Disciplinary Boundaries. Lecture Notes in Statistics 177, Springer-Verlag, London, UK.

Dugmore, A.J., M.J. Church, K.A. Mairs, T.H. McGovern, A.J. Newton, and G. Sveinbjarnardóttir. 2006. An over-optimistic pioneer fringe? Environmental perspectives on medieval settlement abandonment in Dórsmörk, South Iceland. Pp. 335-345, In J. Arneborg and B. Grønnow (Eds.). The Dynamics of Northern Societies. Aarhus University Press, Copenhagen, Denmark.

Dugmore, A.J., M.J. Church, K.A. Mairs, T.H. McGovern, S. Perdikaris, and O. Vesteinsson. 2007. Abandoned farms, volcanic impacts, and woodland management: Revisting Pjórsárdalur, the "Pompeii of Iceland.” Arctic Anthropology 44(1):1-11

Einarsson, E.H., S. Thorarinsson, and G. Larsen. 1980. The Sólheimar tephra and the Katla eruption of ca. 1357. Acta Naturalia Icelandica 28:1-24.

Einarsson, T. 1961. Pollenanalytische untersuchungen zur spat- und postglacialen klimatschichte Islands. Sonderveröff. der Geol. Institut Univer. Köln [SPELL OUT IN FULL] 6:1-52. 
Einarsson, T. 1962. Pollen analytical studies on vegetation, climate. and time of settlement in Iceland (In Icelandic.) Saga 1962:442-469.

Einarsson, T. 1963. Pollen analytical studies on the vegetation and climate history of Iceland in Late and Post-Glacial times. Pp. 355-365, In A. Löve and D. Löve (Eds.). North Atlantic Biota and their History. Pergamon Press, Oxford, UK.

Erlendsson, E. 2007. Environmental Change around the time of the Norse settlement of Iceland. Unpublished Ph.D. Thesis. The Unversity of Aberdeen, Scotland, UK. 301 pp.

Fisher, R.V., and H.U. Schmincke. 1984. Pyroclastic Rocks. Springer Verlag, Berlin, Germany.

Fridriksson, A. 1994. Sagas and Popular Antiquarianism in Icelandic Archaeology. Worldwide Archaeology Series 10, Avebury, Aldershot, UK.

Fridriksson, S. 1973. Life and Land: About Icelandic Ecology. Vardi, Reykjavik, Iceland. 263 pp.

Fridriksson, S. 1988. Erosion rates measured. (In Icelandic with English summary.) Icelandic Agricultural Sciences 1:3-10.

Fridriksson, S. 1995. Alarming rate of erosion of some Icelandic soils. Environmental Conservation 22:167.

Fridriksson, S., and G. Gudbergsson. 1995. Rate of vegetation retreat at rofbarðs. (In Icelandic.) Freyr 1995:224-231.

Gísladóttir, G. 1998. Environmental characterization and change in southwestern Iceland. Department of Physical Geography, Stockholm University, Dissertation Series 10, Stockholm, Sweden.

Gísladóttir, G. 2001. Ecological disturbance and soil erosion on grazing land in southwest Iceland. Pp. 109126, In A. Conacher (Ed.). Land Degradation. Kluwer Academic Publishers, Dordrecht, The Netherlands.

Grönvold, K., N. Óskarsson, S.J. Johnsen, H.B. Clausen, C.U. Hammer, G. Bond, and E. Bard. 1995. Tephra layers from Iceland in the Greenland GRIP ice core correlated with oceanic and land-based sediments. Earth and Planetary Science Letters 135:149-155.

Grove, J.M. 1988. The Little Ice Age. Methuen, London, UK.

Grove, J.M., and R. Switsur. 1994. Glacial geological evidence for the Mediaeval Warm Period. Climatic Change 26:143-169.

Halflidason, H., G. Larsen, and G. Ólafsson. 1992. The recent sedimentation history of Thingvallavatn, Iceland. Oikos 64:80-95.

Hallsdóttir, M. 1987. Pollen analytical studies of human influence on vegetation in relation to the Landnám tephra layer in southwestern Iceland. Lundqua Thesis 18:1-45.

Haraldsson, H. 1981. The Markarfljót sandur area, southern Iceland: Sedimentological, petrological, and stratigraphical studies. Striae 15:1-60.

Jennings, A.E., S. Hagen, J. Harðardóttir, R. Stein, A.E.J. Ogilvie, and I. Jónsdóttir. 1999. Environmental conditions on the southwest Iceland shelf over the last five hundred years. Climatic Change [PROVIDE VOLUME AND PAGE NUMBERS].

Jiang, H., J. Eiríksson, M. Schulz, K.L. Knudsen, and M.S. Seidenkrantz. 2005. Evidence for solar forcing of sea-surface temperature on the North Icelandic shelf during the late Holocene. Geology 33(1):73-76.
Kirkbride, M.P., and A.J. Dugmore. 2005. Late Holocene solifluction history reconstructed using tephrochronology. In C. Harris and J.B. Murton (Eds.). Cryospheric Systems: Glaciers and Permafrost. Geological Society of London Special Publication 242:145-155.

Kjartansson, G., S. Thorarinsson, and T. Einarsson. 1964. The use of C-14 dating for Icelandic Quaternary geology. (In Icelandic). Náttúrufræðingurinn 34:97-145.

Larsen, G. 1981. Tephrochronology by microprobe glass analysis. Pp. 95-102, In S. Self and R.S.J. Sparks (Eds.). Tephra Studies. Reidel, Dordrecht, The Netherlands.

Larsen, G. 1982. Tephrochronology of Jökuldalur and the surrounding areas. Pp. 51-66, In H. Thórarindóttir (Ed.). Eldur er í Nordri. Sögufélag Reykjavíkur, Reykjavík:, Iceland.

Larsen, G. 1984. Recent volcanic history of the Veiðivötn fissure swarm, southern Iceland: An approach to volcanic risk assessment. Journal of Volcanology and Geothermal Research 22:33-58.

Larsen, G. 1996. Tephrochronology and tephra layers from the period of Norse settlement in Iceland. (In Icelandic.) Pp. 81-106, In G.A. Grimsdóttir (Ed.). Um Landáamáa Î́slandi, Ráðstefnurit V. Societas scientarum Islandica, Reykjavik, Iceland.

Larsen, G., and J. Eiríksson. 2008a. Holocene tephra archives and tephrochronology in Iceland: A brief overview. Jökull 58:229-250.

Larsen, G., and J. Eiríksson. 2008b. Late Quaternary terrestrial tephrochronology of Iceland: Frequency of explosive eruptions, type and volume of tephra deposits. Journal of Quaternary Science 23:109-120.

Larsen, G., and S. Thorarinsson. 1977. H4 and other acidic Hekla tephra layers. Jökull 27:28-46.

Larsen, G., A.J. Dugmore, and A.J. Newton. 1999. Geochemistry of historical age silicic tephras in Iceland. The Holocene 9(4):463-471.

LMI (The Icelandic Geodetic Institute). 1993. Digital vegetation index map of Iceland. The Icelandic Geodetic Survey, Reykjavík, Iceland.

Massé, G., S.J. Rowland, M.-A. Sicre, J. Jacob, E. Jansen, and S.T. Belt. 2008. Abrupt climate changes for Iceland during the last millennium: Evidence from highresolution sea-ice reconstructions. Earth and Planetary Science Letters 269:565-569.

Olafsdottir, R., P. Schlyter , and H. Haraldsson. 2001. Simulating Icelandic vegetation cover during the Holocene. Implications for long-term land degradation. Geografiska Annaler 83A(4):203-215.

Runolfsson, S. 1978. Soil conservation in Iceland. Pp. 231-240, In M.W. Holdgate and M.J. Woodman (Eds.). The Breakdown and Restoration of Ecosystems, Plenum Press, New York, NY, USA.

Self, S., and R.S.J. Sparks (Eds.). 1981. Tephra Studies. Reidel, Dordrecht, The Netherlands.

Sicre, M.-A., J. Jacob, U. Ezat, S. Rousse, C. Kissel, P. Yiou, J. Eiriksson, K.L. Knudsen, E. Jansen, and J.-L. Turon. 2008. Decadal variability of sea surface temperatures off North Iceland over the last 2000 years. Earth and Planetary Science Letters 268:137-142.

Sigurbjarnarson, G. 1969. The loessial soil formation and the soil erosion in Haukadalsheidi. (In Icelandic with extended English summary.) Náttúrufræðingurinn 39:49-128. 
Sigurdsson, S. 1977. Birch in Iceland. (In Icelandic.) Pp. 147-172, In H. Gudmundsson et al. (Eds.). Skógarmál, Reykjavík, Iceland.

Simpson, I.A., A.J. Dugmore, A.M. Thomson, and O. Vésteinsson. 2001. Crossing the thresholds: Human ecology and historical patterns of landscape degradation. Catena 42:175-192.

Sparks, R.S.J., M.I. Bursik, S.N. Carey, J.S. Gilbert, L.S. Glaze, H. Sigurdsson, and A.W. Woods. 1997. Volcanic Plumes. Wiley, Chichester, UK. 574 pp.

Stötter, J. 1991. Geomorphologische und landschaftsgeschichtliche Untersuchungen im SvarfaðardalurSkíðadalur, Tröllaskagi, N Island. Münchener Geographische Abhandlungen 9:1-166.

Sveinbjarnardóttir, G. 1982. Settlement ruins at Einhyrningsflatir in Fljótshlíð. Pp. 67-77, In H. Thórarindóttir (Ed.). Eldur er í Norðri. Sögufélag Reykjavíkur, Reykjavík, Iceland.

Sveinbjarnardóttir, G. 1992. Farm abandonment in Medieval and post-Medieval Iceland: A multidisciplinary study. Oxbow Monograph 17:1-192.

Thomson, A.M., and I.A. Simpson. 2007. Modelling historic rangeland management and grazing pressures in landscapes of settlement. Human Ecology 35:151-168.

Thorarinsson, S. 1944. Tefrokronologiska studier på Island. Geografiska Annaler 26:1-217.

Thorarinsson, S. 1956. On the variations of Svinafellsjökull, Skaftafellsjökull, and Kviarjökull in Oraefi. Jökull 6:1-15.

Thorarinsson, S. 1961. Wind erosion in Iceland. A tephrochronological study. (In Icelandic.) Ársrit Skógræktarfélags Íslands 1961:17-54.

Thorarinsson, S. 1967. The eruptions of Hekla in historical times. The eruption of Hekla 1947-1948 1:1-170.

Thorarinsson, S. 1975. Katla and the annals of Katla tephras. (In Icelandic.) Árbók ferðafélags Íslands 1975:125-149.

Thorarinsson, S. 1980. Long-transported tephra from three Katla eruptions. (In Icelandic.) Jökull 30:65-73.

Thorarinsson, S. 1981. The application of tephrochronology in Iceland. Pp. 109-134, In S. Self and R.S.J. Sparks (Eds.). Tephra Studies. Reidel, Dordrecht, The Netherlands.

Thorsteinsson, I. 1978. Vegetation and Land Use. (In Icelandic). Lesarkir Landverndar, Reykjavik, Iceland.

Thoroddsen, T. 1914. An account of the physical geography of Iceland with special reference to the plant life. Botanica Islandica 1(2):187-343.

Thoroddsen, T. 1919. The Description of Iceland III (In Icelandic.) Hid islenska bokmenntafelag, Copenhagen, Denmark.

Thorsteinsson, I. 1986. The effect of grazing on stability and development of Northern rangelands: A case study from Iceland. Pp. 37-43, In O. Gudmundsson (Ed.). Grazing Research at Northern Latitudes. Plenum, New York, NY, USA.

Vésteinsson, O. 1998. Patterns of settlement in Iceland. A study in prehistory. Saga-Book 25(1):1-29 .

Wada K., O. Arnalds, Y. Kakuto, L.P. Wilding, and C.T. Hallmark. 1992. Clay minerals in four soils formed in eolian and tephra materials in Iceland. Geoderma 52:351-365.
Webb, R. 1972. Vegetation cover on Icelandic thufur. Acta Botanica Islandica 1(1972):51-60.

Zielinski, G.A., M.S. Germani, G. Larsen, M.G.L. Baillie, S. Whitlow, M.S. Twicker, and K. Taylor. 1995. Evidence of the Eldgjá (Iceland) eruption in the GISP-2 Greenland ice core: Relationship to eruption processes and climate conditions in the tenth century. The Holocene 5:129-140. 